JOLANTA WASILEWSKA* - LUBLIN

\title{
NAJPIĘKNIEJSZY RĘKOPIS ŚREDNIOWIECZA - KSIĘGA Z KELLS ${ }^{1}$
}

Chrystianizacja dokonana przez św. Patryka² w V wieku spowodowała włączenie Irlandii do Orbis Christianus. Nawrócenie na chrześcijaństwo spowodowało odrodzenie kultury celtyckiej, zachowując przy tym jej starożytne (pogańskie) tradycje. Wraz z rozprzestrzenianiem się chrześcijaństwa irlandzkie klasztory stawały się ważnymi ośrodkami nauczania i piśmiennictwa religijnego, charakteryzując się przy tym niezwykłą dynamicznością i ekspansywnością. Przyczyniły się do tego z jednej strony podróże mnichów irlandzkich na południe Europy (skąd przywozili wzory zdobnictwa orientalnego sztuki graficznej i malarskiej), z drugiej zaś migracje, gdyż do spokojnej wówczas Irlandii, pod naporem Germanów, uciekali z kontynentu ludzie sztuki i nauki. Irlandia stała się doskonałym azylem dla artystów, którzy przeszczepili do kultury celtyckiej wzory zachodnie i orientalne, tworząc w ten sposób oryginalną sztukę iryjską ${ }^{3}$.

\section{Średniowieczne celtyckie manuskrypty}

W Irlandii, która dzięki działalności misyjnej św. Patryka weszła do kręgu kultury chrześcijańskiej, klasztory stały się ważnymi ośrodkami rzemiosła i sztuk plastycznych. Zakonnicy irlandzcy w krótkim czasie zyskali sławę jako bardzo utalentowani kaligrafowie. Natomiast rękopisy iryjskie znane są niemal wyłącznie $\mathrm{z}$ ewangeliarzy powstających w skryptoriach klasztornych na obszarze angloceltyckim w czasie od VII do IX wieku.

* Jolanta Wasilewska - mgr historii sztuki, starszy kustosz dyplomowany w Bibliotece Uniwersyteckiej KUL, e-mail: jolanta.wasilewska@kul.pl

${ }^{1} \mathrm{~W}$ literaturze anglosaskiej znany jako Book of Kells.

${ }^{2}$ Św. Patryk (ok. 385-461) - biskup i apostoł Irlandii, święty Kościoła katolickiego i prawosławnego, misjonarz i organizator życia religijnego w Irlandii. K. Panuś, Święty Patryk, Kraków 2004.

${ }^{3}$ A. Lissowska, Wczesnośredniowieczne iluminatorstwo iryjskie, „Polonia Christiana”, 5 (2008) s. 66. 
Wraz z misjami mnichów irlandzkich, sztuka miniatorstwa rozprzestrzeniła się w wielu krajach Europy, a przede wszystkim na terenie Anglii i północnej Francji. W Anglii najbardziej znanymi przedstawicielami tego nurtu w ornamentyce są wspaniałe rękopisy: Ewangeliarz z Durrow i Ewangeliarz z Linisfarne ${ }^{4}$. Niektóre klasztory w sztuce pisarskiej osiągnęły bardzo wysoki poziom, stwarzając własne szkoły kaligraficzne i odgrywając znamienną rolę w rozwoju pisma łacińskiego. Wytworzył się tam oryginalny typ pisma zwany pismem insularnym, na podstawie półuncjały rzymskiej o charakterze minuskulnym i odznaczało się wysokim stopniem doskonałości graficznej i ornamentalnej. Półuncjała irlandzka wyróżniała się charakterystycznym akcentowaniem zaokrągleń i wzmacnianiem trzonków liter od góry trójkątnymi zakończeniami. W tekstach pisanych półuncjałą wprowadzano także kapitałę, którą stosowano do pisania inicjałów, tytułów i nazw 5 .

Do wytworzenia manuskryptów używano doskonale wyprawionej cielęcej skóry - welinu. Z reguły malarze współpracowali ze skrybami, by stworzyć ciągłość między treścią w tekście a szatą graficzną ją wspomagającą. Skrybowie pisali skośnie przyciętymi łodygami sitowia, trzciny lub ptasimi piórami (najczęściej gęsie, orle i krucze) zaciętymi ukośnie i rozszczepionymi na końcu'. Barwami najczęściej stosowanymi były kolory: czarny, czerwony, fioletowy i żółty, w tym czasie nie używano jeszcze złota i srebra?

Pieczołowicie kaligrafowane i wspaniale dekorowane celtyckie ewangeliarze były mieszaniną różnych tłumaczeń, w znacznej części opartych na wiernej transkrypcji Biblii Wulgaty, ale też na wersjach starołacińskich Biblii, opartych na hebrajskich i greckich manuskryptach. Większość ewangeliarzy insularnych powstałych w Irlandii prezentuje jednolity schemat. Zazwyczaj na początku umieszczano tablice kanoniczne wraz z listem Euzebiusza, następnie Breves causae ${ }^{8}$, a przed każdą ewangelią znajdowały się symbole czterech ewangelistów ${ }^{9}$ i portret ewangelisty ${ }^{10}$. Tekst ewangelii rozpoczynał się bogato dekorowanym dużym

${ }^{4}$ Book of Durrow - 2 poł. VII w. znajduje się w Dublinie w Trinity Gollege Library, sygn. Ms 57 A. 45 Book of Lindisfarne - pocz. VIII przechowywany jest w Londynie w British Museum Cotton, sygn. Ms Nero D.IV. Encyklopedia wiedzy o ksiażce, Wrocław 1971, szp. 1304-1306.

${ }^{5}$ Pismo insularne - pismo łacińskie, które rozwinęło się na wyspach brytyjskich w ciągu VI -VIII wieku, najwcześniej w Irlandii. Kształtowało się na wzór kodeksów, pisanych uncjałą lub półuncjałą, importowanych na wyspy w V-VI wieku. Półuncjała irlandzka pośrednio przyczyniła się do powstania najwspanialszego rodzaju pisma, mianowicie minuskuły karolińskiej. W. Semkowicz, Paleografia łacińska, wyd. II, Kraków 2002, s. 222-224; A. Gieysztor, Zarys dziejów pisma łacińskiego, Warszawa 1973, s. 83-84.

${ }^{6}$ S. Dahl, Dzieje ksiażki, Wrocław 1965, s. 32.

${ }^{7}$ Ultramarynę uzyskiwano z lazurytu afgańskiego, odcienie fioletu i różu pozyskiwano z barwników roślinnych, lśniący złoty kolor uzyskiwano z minerału aurypigmentu, kolor czarny z sadzy i gumy arabskiej. J. Wood, Celtowie - Ludzie, mitologia, sztuka, Warszawa 2002, s. 77.

${ }^{8}$ Krótkie streszczenia starych łacińskich przekładów z Ewangelii.

${ }^{9}$ Człowiek - św. Mateusz, lew - św. Marek, wół - św. Łukasz, orzeł - św. Jan.

${ }^{10}$ Ewangeliści zazwyczaj byli przedstawiani w pozycji siedzącej, często na ozdobnym tronie w bogato udrapowanych szatach i z książką w ręce. Towarzyszyły im symboliczne figury uskrzydlonych emblematów ewangelicznych. 
inicjałem. Tablice - Kanon Euzebiusza ${ }^{11}$ - miały najczęściej bogatą dekorację artystyczną ${ }^{12}$. Zdobnictwo manuskryptów w VII i VIII wieku osiągnęło stopień najwyższego mistrzostwa w sztuce malarskiej i kaligraficznej. Skomplikowane kompozycje oparte na motywach plecionki, spirali, zygzaków, kół, splecionych z nienaturalnie wydłużonymi wyobrażeniami zwierząt (smoki, lwy, węże, ptaki) wzajemnie pochłaniających się i wijących, wypełniają często całą stronę karty rękopisu, tworząc wielki inicjał ${ }^{13}$. Nawet na stronach niemal pozbawionych ilustracji, ściśle pokrytych tekstem, pomiędzy wierszami lub na końcu zdania, pojawiają się wspaniałe (choć niewielkie) akcenty: barwne geometryczne kształty, ozdobne linie, drobne zarysy kwiatków czy gałązek, splatające się formy zwierzęce i roślinne, wreszcie niewielkie postacie. Inspiracje wzorów czerpano z lokalnej tradycji prymitywnej celtyckiej sztuki zdobniczej i skomplikowanych ornamentów zwierzęcych zapożyczonych ze sztuki anglosaskiej ${ }^{14}$. W dekoracji tekstów iryjskich ozdobny inicjał wyjątkowo zdominował tekst; począwszy od małych inicjałków obwiedzionych czerwonymi punkcikami, charakterystycznej cechy kaligrafii wyspiarskiej, aż do wielkich inicjałów zajmujących całą powierzchnię karty ${ }^{15}$. Duże inicjały przedstawiają niezwykłe bogactwo motywów i form linearno-geometrycznych, akcentując szczególnie typowy motyw iryjskiej plecionki wstęgowej oraz spirali, których ornamentyka niejednokrotnie kryła w sobie symbole i obrazy będące komentarzem do tekstu ${ }^{16}$. Charakterystycznymi dla zdobnictwa rękopisów

${ }^{11}$ Kanon Euzebiusza - system odniesień pomiędzy paralelnymi tekstami (fragmentami) zamieszczanych przed każdą z czterech Ewangelii, opracowany w 1. połowie IV w. przez Euzebiusza z Cezarei. Kanon Euzebiusza stosowany był w licznych rękopisach Ewangelii późnej starożytności i w średniowieczu. F. Drączkowski, Euzebiusz z Cezarei, w: Encyklopedia katolicka, t. 4, Lublin 1983, kol. 1354.

${ }^{12}$ I tak dla ewangeliarzy charakterystyczne są umieszczone zwyczajnie na początku księgi tablice „kanonów”, zawierające konkordancje czyli zestawienia odpowiadających sobie rozdziałów czterech ewangelii. podzielone są na 2, 3 i 4 szpalty ozdobnymi, ze wschodnim przepychem wymalowanymi kolumnami, które górą połączone są arkadkami, nad nimi zaś wznosi się niekiedy jeden wielki łuk, wypełniony znanymi symbolami ewangelistów. Semkowicz, Paleografia łacińska, s. $83-84$.

${ }^{13}$ Pogańska sztuka zdobnicza, dotychczas wykorzystywana do upiększania klejnotów i przedmiotów użytku codziennego, zaczęła przedostawać się na teren sztuki chrześcijańskiej, także w zakresie zdobnictwa książkowego. Badania archeologiczne wykazują, że charakterystyczne plecionkowe, spiralne i zoomorficzne motywy celtyckie i germańskie, pierwotnie zdobiące biżuterię, naczynia użytkowe, uprzęże, hełmy, tarcze i inne przedmioty, zostały bezpośrednio przeniesione do sztuki chrześcijańskiej. Lissowska, Wczesnośredniowieczne iluminatorstwo iryjskie, s. 67.

${ }^{14} \mathrm{~W}$ zdobnictwie manuskryptów czerpano wzory z prymitywnej zdobniczej sztuki celtyckiej, ozdób na skórze i metalu oraz kamiennych krzyży. R. Bulas, Irlandia między epoka kamienia a średniowieczem, Poznań 2000, s. 8-10.

${ }^{15} \mathrm{~K}$. Głombiowski, H. Szwejkowska, Książka rękopiśmienna i biblioteka w starożytności $i$ średniowieczu, Warszawa 1987, s. 105.

${ }^{16}$ Swoimi korzeniami motyw ten sięga wzorów plecionki obecnych w kulturze epoki lateńskiej, która kwitła w Europie w okresie od 500 r. p.n.e. do pierwszych stuleci naszej ery. W późniejszym okresie motyw misternych splecionych węzłów rozwijał się głównie w Irlandii i swoją najwspanialszą postać osiągnął w ornamentach zdobiących manuskrypty z VII-IX wieku. Wood, Celtowie - Ludzie, mitologia, sztuka, s. 79. 
celtyckich są całe strony czysto dekoracyjne, znane jako strony kobiercowe czy dywanowe. Nazywane tak ze względu na ich podobieństwo do orientalnych dywanów związanych z kulturą Bliskiego Wschodu, były one wspólne dla wszystkich wyspiarskich rękopisów ${ }^{17}$.

Najpiękniejsze celtyckie rękopisy, które powstały w okresie od VII do IX wieku, należą do najznakomitszych arcydzieł sztuki wyspiarskiej, ale także europejskiej. Najbardziej znanymi dziełami sztuki iryjskiej są dwa ewangeliarze: Book of Durrow z poł. VII wieku i Book of Kells z ok. 800 roku. Manuskrypty tego okresu dzielą się na dwa typy: wielkoformatowe Ewangelie starannie pisane uncjałą lub półuncjałą przeznaczone były do użytku liturgicznego, oraz małe książki pisane kursywą przeznaczone do prywatnego użytku ${ }^{18}$. Rękopisy powstałe w tym czasie na wyspach charakteryzują się dużym podobieństwem graficznym i tekstowym. Do tej samej grupy charakteryzującej się znacznym podobieństwem artystycznym, pisma oraz tradycji tekstowej można zaliczyć: Cathach św. Kolumby, Ambrosiana Orosius i Księga z Durrow (wszystkie z VII wieku). Z początku VIII wieku pochodzą m.in. Ewangeliarz z Durham, Ewangeliarz z Echternach, Ewangeliarz z Lindisfarne oraz Ewangeliarz z Lichfield. Z końca VIII wieku do najbardziej znanych należą: Ewangeliarz z Sankt Gallen i Ewangeliarz z Macregal. Księga z Armagh (datowana na 807-809), tzw. Pryscjan z Leiden oraz Pryscjan z Sankt Gallen powstały zaś na początku IX wieku' ${ }^{19}$.

\section{Pochodzenie i dzieje}

Księga z Kells (łac. Codex Cenannensis, ang. Book of Kells, irl. Leabhar Cheanannais), znana jest również pod nazwą Ewangeliarz z Kells lub Ewangeliarz świętego Kolumby (Kolumbana) ${ }^{20}$. Nazwa księgi pochodzi od miejscowości

${ }^{17}$ Carpet pages are fully ornamented representations of precisely balanced geometric patterns, densely embellished with discs, spirals and interlacing. These somewhat mysterious artistic forms may have had their origins in Coptic and Oriental art. They do appear in other Insular Manuscripts, the earliest being in the seventh century Ambrosiana Orosius, as well as in the Book of Durrow and the Lindisfarne Gospels. Ch. Giddley, The Book of Kells, Del Mar 2011 http://www.arinabooks.com/ uploads/2/0/7/7/20775746/_bookofkells_first_50.pdf (dostęp: 12.08.2015 r.)

${ }^{18}$ M. Dillon, N.K. Chadwick, Ze świata Celtów, Warszawa 1975, s. 306.

${ }^{19} \mathrm{~W}$ pełni dojrzały styl ornamentacji z bogactwem iluminacji pozwala na umieszczenie Księgi z Kells wśród późniejszych dzieł z tej grupy i datować ją na koniec VIII lub początek IX wieku, a więc na ten sam okres co Księga z Armagh. W dziele zachowana jest większość norm ikonograficznych i stylistycznych obecnych w starszych rękopisach: na przykład kształt dekoracyjnych liter otwierających cztery Ewangelie zadziwiająco regularnie się powtarza we wszystkich manuskryptach powstałych na wyspach [Brytyjskich] w tej epoce. Wystarczy porównać pierwsze stronice Ewangelii według św. Mateusza w Ewangeliarzu z Lindisfarne oraz w Księdze z Kells. https://pl.wikipedia. org/wiki/Ksi\%C4\%99ga_z_Kells (dostęp: 12.08.2015 r.)

${ }^{20}$ Imię pochodzenia łacińskiego oznaczające gołębicę. Występuje w formie żeńskiej i męskiej. Imię to często nadawano mnichom w klasztorach iroszkockich. H. Fros, F. Sowa, Księga imion i 
Kells w Hrabstwie Meath w Irlandii, a właściwie od opactwa w Kells, gdzie była przechowywana przez większość średniowiecza. Data i miejsce powstania rękopisu nie są dokładnie znane ${ }^{21}$. Istnieje co najmniej pięć różnych koncepcji co do miejsca i czasu powstania księgi: mogła ona być

1. spisana na wyspie Iona i przewieziona do opactwa Kells

2. rozpoczęta na Ionie i kontynuowana w Kells

3. w całości napisana w Kells

4. wytworzona w północnej Anglii, np. w Lindisfarne, następnie przeniesiona na wyspę, a stamtąd do Kells

5. spisana na terenie piktyjskiej Szkocji, będącej terenem misyjnym św. Kolumby i siedzibą wielu wspólnot monastycznych, które założy ${ }^{22}$.

Niezależnie od tego, która wersja jest prawdziwa jest niemal pewne, że Księga z Kells wywodzi się z klasztoru założonego w VI wieku przez irlandzkiego mnicha św. Kolumbę ${ }^{23}$ na wyspie Iona ${ }^{24}$. Iona stanowiła jedną $z$ najważniejszych wspólnot monastycznych w tym regionie i jedno z ważniejszych centrów kultury monastycznej. W początku IX wieku, w czasie nasilenia najazdów wikingów, wyspa była częstym celem ich ataków, co spowodowało, że większość mnichów przeniosła się do Kells ${ }^{25}$, które stało się nowym ośrodkiem wspólnot kolumbańskich. Do Kells przewieziono relikwie św. Kolumby i najcenniejsze rzeczy, $\mathrm{w}$ tym ewangeliarz bogato oprawiony w szlachetne kamienie. O tym, że księga na początku XI wieku znajdowała się w Kells świadczy wpis w Annałach Ulsteru w $1007 \mathrm{roku}^{26}$. Wpis informuje, że księgę ukradli złodzieje; po kilku miesiącach odnaleziono ją w pobliżu klasztoru pod zwałem ziemi, ale już bez cennej opra-

świętych, t. 3, Kraków 1998, s. 505.

${ }^{21}$ Data i miejsce produkcji rękopisu były przedmiotem poważnych debat. Tradycyjnie uważa się, że książka została utworzona w czasach Kolumbana. Większość dowodów wskazuje jednak na datę ok. 800 r., długo po śmierci św. Kolumbana w 597 r. https://en.wikipedia.org/wiki/Book_of_ Kells (dostęp: 10.08.2015 r.)

${ }^{22} \mathrm{https} / / /$ pl.wikipedia.org/wiki/Ksi\%C4\%99ga_z_Kells (dostęp: 23.08.2015 r.)

${ }^{23}$ Św. Kolumba (znany też jako św. Kolumban, św. Columba z Hy, św. Colum Cille - 521-597) - apostoł Irlandii, opat i misjonarz, jeden z 12 apostołów Irlandii, święty Kościoła katolickiego i anglikańskiego, prawosławny święty mnich. Prawdopodobnie w 563 r. opuścił Irlandię wraz z 12 towarzyszami i założył opactwo na wyspie Iona. D. Ó Cróinín, Irlandia średniowieczna: (400-1200), Warszawa 2010, s. 298-299.

${ }^{24}$ Wyspa Iona leży u zachodniego wybrzeża Szkocji, zaliczana jest do Archipelagu Hybrydów Wewnętrznych. Siedziba ufundowanego przez św. Kolumbę, w 563 r. klasztoru, jednego z pierwszych i ważniejszych zakonów na obszarach celtyckiej Irlandii, Szkocji i Walii. J. Strzelczyk, Iroszkoci w kulturze średniowiecznej Europy, Poznań 2008, s. 44.

${ }^{25}$ The majority of the monks of Iona abandoned the monastery after a Viking attack in 806 and sought refuge in Kells. B. Maier, Dictionary of Celtic Religion and Culture, Woodbridge 2000, s. 40; Napaści ponawiały się przez całą następną dekadę, zmuszając mnichów do ucieczki z Iony do Irlandii. Musieli ratować siebie i cenne relikwie św. Kolumby. Klasztor na wyspie Iona wikingowie spalili w 802 r. Ó Cróinín, Irlandia średniowieczna, s. 298.

${ }^{26}$ The Great Gospel of Colum Cille was wickedly stolen by night from the western sacristy in the great stone church of Cenannas. It was the most precious object of the western world on account of the human ornamentation. This Gospel was recovered after two months and twenty nights, its 
$w^{27}$. Pozbawienie oprawy thumaczy zapewne brak ok. 30 kart z początku i końca dzieła $^{28}$. Brakuje także dwóch kart z portretami Ewangelistów św. Marka i św. Łukasza oraz karty z symbolami Czterech Ewangelistów, która powinna znajdować się przed Ewangelią św. Łukasza. Kolejnym dowodem na to, że księga znajdowała się w opactwie Kells są sporządzone na kilku pustych kartach notatki dotyczące ziem będących w posiadaniu klasztoru ${ }^{29}$. W XII wieku w wyniku reformy kościelnej opactwo i klasztor Kells zostało rozwiązane ${ }^{30}$. Kościół trafił pod zarząd parafii, a księga była tam przechowywana aż do 1654 roku, kiedy to w budynkach poklasztornych założono garnizon dla wojsk Oliviera Cromwella. Gubernator miasta dla bezpieczeństwa przekazał rękopis do Dublinia, gdzie trafił pod opiekę Henry'ego Jones'a, późniejszego biskupa Meath ${ }^{31}$, a w 1661 roku arcybiskup James Ussher przekazał go do Trinity College, gdzie został oficjalnie wpisany do inwentarza tamtejszej Biblioteki ${ }^{32}$.

W ciągu wieków rękopis był kilkakrotnie oprawiany. Niestety w XVIII wieku introligator nieostrożnie nazbyt przyciął pergaminowe karty, co spowodowało bezpowrotną utratę fragmentów iluminacji. Po nietrwałej oprawie wykonanej w 1895 roku część kart oddzieliła się od całości. W 1953 roku introligator Roger Powell ${ }^{33}$ oprawił rękopis w cztery tomy. W roku 2000 tom zawierający Ewangelię św. Marka został wypożyczony na wystawę poświęconą iluminowanym manuskryptom w Canberze w Australii; niestety podczas transportu drogą powietrzną wolumin doznał drobnych uszkodzeń pigmentu ${ }^{34}$.

gold having been taken off it and with a sod over it. The Annals of Ulster, p. 437, http://www.ucc.ie/ celt/published/T100001A/ (dostęp: 13.05.2015 r.)

${ }^{27}$ Evidence of its whereabouts is alluded to in the Annals of Ulster, which in 1007 records: ...the great Gospel of Columcille (Columba), the chief relic of the Western World, was wickedly stolen during the night from the western sacristy of the great stone church at Cenannas (Kells) on account of its wrought shrine. The chronicle goes on to note that the book was found nearby some two months later buried under sod, its wooden and gold metalwork covers torn off. This violent handling would account for the fact that a number of pages at the beginning and end of the book are missing. CH. Giddley, The Book of Kells, Del Mar 2011. http://www.arinabooks.com/ uploads/2/0/7/7/20775746/_bookofkells_first_50.pdf (dostęp: 13.05.2015 r.)

${ }^{28}$ The present manuscript consists of 340 folios or 680 pages. It is possible that the original had 370 folios (740 pages). Tamże.

${ }^{29}$ Nanoszenie takich adnotacji na kartach nawet cennych ksiąg było w średniowieczu dość częstą praktyką. Czyniono to ze względu na koszt i trudną dostępność materiałów piśmiennych.

${ }^{30} \mathrm{Kells}$ was in fact the headquarters of yhe Columban league from the ninth century onwards and an important synod was held there in 1152. M. Low, Celtic Christianity and Nature, Edinburgh 1996, s. 53.

${ }^{31}$ Biskup Meath, Henry Jones, przekazał księgę do Trinity College w Dublinie. Ó Cróinín, Dáibhí, Irlandia średniowieczna, s. 298.

${ }^{32}$ B. Maier, Dictionary of Celtic religion and Culture, Woodbridge 2000, s. 40.

${ }^{33}$ Powell left Cockerell \& Son in 1947 and again set up his own bindery in Froxfield, Hampshire. Here he did some of his most notable work, including the rebinding of the Book of Kells and Book of Durrow in 1953, the Lichfield Gospels in 1962, and work on many other important historical. https://en.wikipedia.org/wiki/Roger_Powell_\%28bookbinder\%29 (dostęp: 13. 05. 2015 r.)

${ }^{34}$ https://pl.wikipedia.org/wiki/Ksi\%C4\%99ga_z_Kells (dostęp: 23.08.2015 r.) 


\section{Opis fizyczny}

Kodeks jest dość dużych rozmiarów - obecnie ma wymiary ok. 330×255 mm. Jak się przypuszcza, początkowo karty nie były jednakowej wielkości ${ }^{35}$. Rękopis składa się ze $340 \mathrm{kart}$ tzW. folio ${ }^{36}$. Większość folio stanowi faktycznie część większych arkuszy, tzw. bifolio, które złożone na pół dają dwa folio. Wiele bifolio zostało złożonych razem i zszytych ze sobą, tworząc składki. Kilka folio są po prostu pojedynczymi kartami wstawionymi w składkę.

Dzieło spisane jest na dość grubym wypolerowanym welinie (pergamin) 37 ; szacuje się, że na księgę zużyto skóry ze stu pięćdziesięciu cieląt. Karty pergaminowe mają jednak różną grubość - w wielu miejscach są tak cienkie, że tekst i dekoracje przebijają na drugą stronę. Strony tekstowe mają od 16 do 18 wersów (linii). Tekst i iluminacie pokrywają obie strony, tj. recto i verso. W księdze znajduje się kilka stron niezapisanych. Poszczególne części księgi spisano majuskułą insularną, używając atramentu czarnego, żółtego, czerwonego i fioletowego. Nad rękopisem pracowało co najmniej trzech skrybów i pięciu miniaturzystów, stosujących odmienną technikę i zestawienia kolorystyczne ${ }^{38}$.

\section{Zawartość księgi}

Księga z Kells zawiera cztery Ewangelie Nowego Testamentu, bazujące na Wulgacie. Ewangelie te nie prezentują wiernego przekładu Biblii (mają liczne odstępstwa od tekstu autorstwa św. Hieronima), ponieważ korzystano także z innych wcześniejszych łacińskich tłumaczeń. Rękopis powstał w większości na podstawie reguł ikonograficznych i stylistycznych zaczerpniętych ze starszych dzieł ${ }^{39}$. Napisana jest po łacinie, zawiera pełen tekst Ewangelii wg św. Mateusza, Marka i Łukasza oraz Ewangelii wg św. Jana do $17,13^{40}$, poprzedzonych notami wstęp-

${ }^{35}$ The leaves of the Book of Kells, because of trimming by a later hand, measures $13 \times 99^{1 / 2}$ inches. Encyclopedia International, New York 1969, s. 140.

${ }^{36}$ Folio - arkusz raz złamany tworzy składkę z dwóch kart, złamany dwa razy daje quarto (cztery karty).

${ }^{37}$ Nazwa pochodzi od łacińskiego słowa vitulinum, czyli wykonane z cielaka. Słowo velin pochodzi z dawnego języka francuskiego, oznacza cielę. Termin często odnosi się do pergaminu wykonanego z cielęcej skóry. E. Diehl, Bookbinding, Vol. 2, New York. 1980, s. 310.

${ }^{38}$ Wood, Celtowie - ludzie, mitologia, sztuka, s. 80.

${ }^{39}$ The text of the manuscript is mix of translations. Some sections feature a pure transcription of the Vulgate, while others are rendered in various forms of what is known as Old Latin, or Vetus Latina. The Vulgate Bible was in major part the work St. Jerome who in 382, at the behest of Pope Damasus I, revised Old Latin versions of the Bible, based upon Greek and Hebrew manuscripts. Others participated in what would become a complete revision of the Bible along the lines of St. Jerome's methodology. This Vulgate Bible came to be known as the version vulgate, or "commonly used translation," and was eventually recognized by the Roman Catholic Church as the official text of the Bible. Old Latin versions would have been familiar to Columban monks. They were a legacy of the translations of Roman texts handed down from the earliest missionaries who began Ireland's conversion to Christianity in the fifth century. CH. Giddley, The Book of Kells, Del Mar 2011 http:// www.arinabooks.com/uploads/2/0/7/7/20775746/_bookofkells_first_50.pdf(dostęp: 13.05.2015 r.)

${ }^{40}$ Jak się przypuszcza, rękopis nie został dokończony, ale jest też możliwe, że ostatnie karty zaginęły. 
nymi i komentarzami. Przed rozpoczęciem każdego tekstu Ewangelii wprowadzono cykle miniatur całostronicowych; najczęściej są to symbole czterech Ewangelistów, ich portrety oraz ozdobnie potraktowane duże inicjały, często zajmujące całą płaszczyznę karty. Dodatkowo, w kilku przypadkach, znajdziemy ilustracje całostronicowe nawiązujące do konkretnych fragmentów tekstu.

Księgę rozpoczyna strona podzielona pionową linią na dwie części: w jednej części znajduje się lista imion hebrajskich zawartych w Ewangeliach, w drugiej symbole czterech Ewangelistów ułożone w zmienionej kolejności: Łukasza, Jana, Mateusza i Marka. Imiona te odnoszą się do Ewangelii Mateusza (f.1r). Spis imion hebrajskich znajduje się jeszcze w jednym, nietypowym miejscu bo za Breves causae św. Jana. Pierwszy fragment (f.26r) zawiera końcówkę listy dotyczącej Ewangelii według św. Mateusza (brakujące w niej imiona zajmowałyby dodatkowe dwa folio). Drugi fragment (f.26v) dotyczy Ewangelii według św. Łukasza. Pełna lista wymagałaby dodatkowych trzech folio. W księdze nie ma list dotyczących Ewangelii według św. Marka i św. Jana ${ }^{41}$.

Za pierwszym fragmentem listy znajdują się tablice kanonów Euzebiusza z Cezarei. Mają one bogatą dekorację artystyczną w kształcie arkad, obejmujących kolumny numerów paralelnych tekstów Ewangelii. Tablice Kanonu I (f.1v-f.2r) odnoszą się do czterech Ewangelistów i umieszczone są w czterech przęsłach arkad. Dalej w pięknie zdobionych symbolami Ewangelistów arkadach (ale już trójdzielnych) znajdują tablice Kanonu II (f.2v-f.3r), odnoszące się do Ewangelii św. Marka, św. Mateusza i św. Łukasza. Następnie pomiędzy czterema kolumnami arkady wypisano tablice Kanonu II (f.3v), odnoszące się do Ewangelii św. Marka, św. Mateusza i św. Łukasza oraz tablice Kanonu III (f.4r), przypisane do Ewangelii św. Mateusza, św. Łukasza i św. Jana. Na stronie obok umieszczone także w ozdobnej arkadzie tablice Kanonu IV odsyłają do Ewangelii Św. Mateusza, św. Marka i św. Jana. Tablice Kanonu V dotyczą Ewangelii św. Marka i św. Łukasza (f.4v). Całość kończą tablice Kanonów VI, VII, VIII, odnoszące się do czterech Ewangelistów (f.5r) ${ }^{42}$. Za tablicami znajdują się Breves causae ${ }^{43}$

${ }^{41}$ The structure of the quire in which folio 26 occurs is such that it is unlikely that there are three folios missing between folios 26 and 27, so that it is almost certain that folio 26 is not now in its original location. https://en.wikipedia.org/wiki/Book_of_Kells (dostęp: 19.08.2015 r.)

${ }^{42}$ The tables in the Book of Kells, however, are almost unusable because the scribe condensed the tables in such a way as to make them confused. In addition, the corresponding chapter numbers were never inserted into the margins of the text, making it impossible to find the sections to which the canon tables refer. The reason for the omission remains unclear: the scribe may have planned to add the references upon the manuscript's completion, or he may have deliberately left them out so as not to spoil the appearance of pages. Tamże.

${ }^{43}$ Breves causae to streszczenia starołacińskich przekładów Ewangelii. Dzielą się one na ponumerowane rozdziały. Numerów rozdziałów, tak samo jak numerów w tablicach kanonicznych, nie użyto na stronach manuskryptu. Jednak, najprawdopodobniej i tak nie korzystano by z tych numerów, nawet gdyby manuskrypt został ukończony, gdyż odpowiadały starym łacińskim przekładom i trudno byłoby je dopasować do tekstu Wulgaty. https://pl.wikipedia.org/wiki/Ksi\%C4\%99ga_z_Kells (dostęp: 19.08.2015 r.) 
podzielone na ponumerowane rozdziały ${ }^{44}$. Po nich umieszczone są Argumenta ${ }^{45}$ czyli zbiory legend o Ewangelistach. Breves causae i Argumenta ułożone są w nietypowej kolejności: pierwsze Breves i Argumenta dla św. Mateusza (f.8r -12v), następnie Breves causae i Argumenta dla św. Marka (f.13r-19v), a później, dość zaskakująco, Argumenta dotyczące św. Łukasza i św. Jana i dalej Breves causae dla św. Łukasza i św. Jana (f.19v-f.25v) ${ }^{46}$.

Breves Cause św. Mateusza rozpoczyna całostronicowa miniatura przedstawiająca Matkę Boską z Dzieciątkiem i Aniołami (f.7v), uważana za najstarszą zachowaną tego typu kompozycję w zachodniej sztuce iluminatorskiej ${ }^{47}$. Jest to właściwy wstęp do początku Breves causae św. Mateusza, które rozpoczyna ozdobnie wypisane zdanie zaczynające się dużym inicjałem: Nativitas XPI in Bethlehem Iudae $e^{48}$, otoczone dekoracyjną bordiurą (f.8r).

Ewangelię św. Mateusza (f.27v-f.129v) poprzedza ilustracja z symbolami czterech Ewangelistów (f.27v), następnie portret św. Mateusza (f. 28v) oraz wielki inicjał wprowadzający w tekst, który zaczyna łaciński incipit: Liber generationis Jesu Christi... ${ }^{49}$ (f.29r). Na stronach ewangelii znajdują się trzy unikalne miniatury. Pierwsza to wizerunek Chrystusa jako Maiestas Domini ${ }^{50}$ - Chrystus

${ }^{44}$ These chapter numbers, like the numbers for the canon tables, are not used on the text pages of the Gospels. It is unlikely that these numbers would have been used, even if the manuscript had been completed, because the chapter numbers corresponded to old Latin translations and would have been difficult to harmonise with the Vulgate text. https://en.wikipedia.org/wiki/Book_of_Kells (dostęp: 19.08.2015 r.)

${ }^{45}$ Argumenta - zbiory legend na temat czterech Ewangelistów.

${ }^{46}$ The summaries and legends of Matthew and Mark appear in order but are then followed, inexplicably, by the Argumenta of Luke and John, the Breves causae of Luke and finally the Breves causae of John. Why this occurred remains open to speculation. This disordered presentation does not exist in any of the other Insular Manuscripts except for the Book of Durrow, in which the sequence of these chapters is almost identical to the sequence in the Book of Kells. Some scholars have suggested the possibilitythat the Kells' scribe, who may have had access to the Book of Durrow in his abbey's library, simply copied that older manuscript's presentation. Although we cannot know the real reason for the disordered sequence in which these chapters are presented, we can offer a credible assumption as to why the Breves causae and Argumentum of each of the four Evangelists have been put in the Preliminaries section and not, as they are in other Insular Manuscripts, separately as prefatory material to each Evangelist's Gospel. Although the scribes and artists of the Book of Kells could sometimes be careless with their presentations of human inventions (Canon Tables, Breves causae and Argumentum) they were far stricter with the sacred text of the Gospels and seemed determined to keep them free of any intrusions that would compromise the purity of the Holy Word. CH. Giddley, The Book of Kells, Del Mar 2011 http://www.arinabooks.com/ uploads/2/0/7/7/20775746/_bookofkells_first_50.pdf(dostęp: 13.05.2015 r.)

${ }^{47}$ Ta pełnostronnicowa ilustracja z Księgi z Kells przedstawia Matkę Boską z Dzieciątkiem na rękach, wokół której fruwają anioły cieszące się z narodzenia Chrystusa. Matka Boska była nie tylko najważniejszą postacią kobiecą występującą w iluminacjach zdobiących manuskrypty, ale także jedyną kobietą, którą wolno było nazwać z imienia. Wood, Celtowie - Ludzie, mitologia, sztuka, s. 84

${ }^{48}$ Jezus narodził się w Betlejem w Judei. Mt 2:1 (wszystkie tłumaczenia z łaciny z http://biblia. deon.pl/).

${ }^{49}$ Księga rodowodu Jezusa Chrystusa... Mt 1:1

${ }^{50}$ Chwała Panu. 
siedzący na tronie z niskim oparciem, otoczony pawiami - symbolem zmartwychwstania (f.32v). Druga miniatura - tzw. kobierzec - przedstawia krzyż o podwójnych ramionach, składający się z ośmiu kół udekorowanych skomplikowanymi i delikatnymi wzorami (f.33r). W tekście Ewangelii Mateusza znajduje się uważany za jeden $\mathrm{z}$ najpiękniejszych chrystogramów ${ }^{51}$. Jest to strona, na której widnieje monogram Chi-Rho ${ }^{52}$, utworzony przez dwie greckie litery $\mathrm{X}$ (chi) oraz $\mathrm{P}$ (rho), które razem z literami (zapisanymi iryjska majuskułą) u dołu strony tworzą skrót od: Christi autem generatio ${ }^{53}$ (f.34r). Monogram Chi Rho bardziej znany jest jako monogram Wcielenia. Trzecią pełną stroną miniaturową, która przedstawia konkretne zdarzenie w tekście Ewangelii, jest scena pojmania Chrystusa w Ogrodzie Getsemani, umieszczona w ozdobnej arkadzie (f.114 r), która poprzedza stronę z dekoracyjnie potraktowanym zdaniem: Tunc dicit illis IHS omnes vos scan [dalum] ${ }^{54}$ (f.114v). Ostatnim ozdobnie wypisanym zdaniem w Ewangelii jest: Tunc crucifixerant XPI cum eo duos latrones ${ }^{55}$ (f.124r). Odnosi się ono do ukrzyżowania Jezusa.

Ewangelia Marka (f.129v-f.187r) zaczyna się od strony z symbolami czterech ewangelistów (f.129v) i strony wprowadzającej z całostronicowym ozdobnym inicjałem zaczynającym zdanie: Initium Evangelium Iesu XPI Filii Dei ${ }^{56}$ (f.130r). Brakuje portretu św. Marka ${ }^{57}$. Również w tej Ewangelii są dwie strony ozdobnego całostronicowego tekstu. Pierwsza przedstawia ukrzyżowanie (f.183r) i zawiera słowa Erat autem hora tertia ${ }^{58}$. Druga strona występuje na końcu Ewangelii i dotyczy wniebowstąpienia (f.187v).

Ewangelia św. Łukasza (f.188r-f.290r) zaczyna się od strony wprowadzającej (f.188r), ale w tym przypadku brakuje portretu Ewangelisty i symboli czterech ewangelistów. Litery osadzone w zdobionej ramie wprowadzają do Ewangelii: Quoniam $^{59}$. Ciąg dalszy kontynuowany jest na stronie odwrotnej (f.188v), wymyślnie dekorowaną literą $f$ (utworzoną z rysunku cielaka o wydłużonym ciele splecionego z winoroślą i rybami) zaczynającą zdanie: Fuit diebus Herodis ${ }^{60}$. Ciekawą parę ilustracji tworzą z jednej strony miniatura przedstawiająca kuszenie Chrystusa (f.202v) i strona z ozdobnym tekstem (f.203r), w którym osadzone są

${ }^{51}$ Chrystogram - monogram będący symbolem Jezusa Chrystusa w formie akronimu.

${ }^{52}$ Karta ta jest najwspanialszym przykładem zdobnictwa inicjałów, które dzięki misternym i delikatnym motywom wywołuje wrażenie ruchu. Szczegóły iluminatorskie tego wielkiego inicjału są niemal nie widoczne dla oka patrzącego. A. B. Jaworska, Anglo-iryjska szkoła iluminatorska w: Wirtualna historia książki i bibliotek, Kraków 2002 http://www.wsp.krakow.pl/whk/konkurs/szkola. html

${ }^{53} \mathrm{Z}$ narodzeniem Chrystusa. Mt 1:18

${ }^{54}$ Wtedy Jezus rzekł do nich: Wy wszyscy zwątpicie. Mt 26:31

${ }^{55}$ Wtedy też ukrzyżowano z Nim dwóch złoczyńców. Mt 27:38

${ }^{56}$ Początek Ewangelii o Jezusie Chrystusie, Synu Bożym.

${ }^{57}$ Whether this was lost or simply never done remains in question. CH. Giddley, The Book of Kells, Del Mar 2011. http://www.arinabooks.com/uploads/2/0/7/7/20775746/_bookofkells_ first_50.pdf (dostęp: 13.05.2015 r.)

${ }^{58}$ Była godzina trzecia Mk 15:25

${ }^{59} \mathrm{Od}$ wielu (Quoniam quidem multi) Łk 1:1

${ }^{60} \mathrm{Za}$ dni Heroda. Łk 1:5 
słowa: IHS autem plenus SB SSCO regressus regressus ${ }^{61}$. Ostatnim przedstawieniem całostronicowym jest zdobiony tekst obwieszczający historię o zmartwychwstaniu Jezusa, ze słowami: Una autem sabbati valde dilu[culo] ${ }^{62}$ (f.285r).

Ewangelia św. Jana (f.290v-f.339v) zaczyna się stroną z symbolami czterech ewangelistów (f.290v), dalej jest portret Ewangelisty (f.291v) oraz strona wprowadzająca $\mathrm{z}$ ozdobnym inicjałem. Na portrecie św. Jan ukazany jest $\mathrm{z}$ uniesioną książką, co o tyle jest znamienne, że głównym tematem zaczynającym Ewangelie jest: In principio erat verbum ${ }^{63}$ (f.292r). Tekst jest przystrojony dwiema postaciami ludzkimi, gdzie mniejsza figura, pokazana z profilu w prawym rogu inicjału to Jan, podczas gdy większa figura stojąca centralnie u góry i trzymająca książkę jest antropomorficzną ikoną przedstawiającą Słowo Boże ${ }^{64}$. Uważa się, że strony z miniaturami dotyczącymi Męki i Wniebowstąpienia oraz Ukrzyżowania i Zmartwychwstania zostały utracone po kradzieży manuskryptu ${ }^{65}$

Dekoracja książki nie ogranicza się do dużych inicjałów na stronach. Ozdabiając duże inicjały iluminatorzy mogli zaprezentować cały swój artystyczny talent, wyobraźnię i kunszt. Ale wszystkie inicjały, małe i większe, zadziwiają wyrafinowanymi motywami, liniami i barwami, które układają się w fantastyczne zwierzęta, ptaki, rośliny, a nawet postacie ludzkie ${ }^{66}$. W całym tekście znajdują się rozrzucone ozdobione małe inicjały i małe figurki zwierząt oraz ludzi często skręcone i powiązane ze sobą w skomplikowane sploty. Strona zawierająca tekst błogosławieństwa w Ewangelii Mateusza (f.40v) wyróżnia się dekoracją wzdłuż lewego marginesu, w którym litera $b$ zaczyna każdy wiersz tworząc ozdobny łańcuch. W genealogii Chrystusa, zawartej w Ewangelii Łukasza (f.200r), odnajdziemy podobną figurę, w której słowo qui wielokrotnie łączy się wzdłuż lewego marginesu.

W całej księdze znajduje się ponad dwa tysiące ozdobnych inicjałów, ale nie odnajdzie się dwóch identycznych. Jakby tego było mało, jeśli na końcu wersetu czy rozdziału zostawało wolne miejsce, ilustrator zapełniał je małą grafiką zwierzęcia lub ptaka. Wiele małych rysuneczków zwierząt, rozsianych w całym tekście, służy do oznaczenia istotnych miejsc i szybkiej ich identyfikacji.

Najbardziej charakterystyczną ozdobą w Księdze z Kells są zwinięte i wzajemnie przeplatające się spirale, kończące się w tak zwany wzór trąbki. Niemal równie charakterystyczne są zoomorficzne przeploty, kolorowe przedstawienia

${ }^{61}$ Pełen Ducha Świętego, powrócił Jezus. Łk 4:1

${ }^{62} \mathrm{~W}$ pierwszy dzień tygodnia, bardzo wcześnie rano. Łk 24:1 http://www.liturgia.cerkiew.pl/ pages/File/docs/czas-07-ewangelie.pdf

${ }^{63} \mathrm{Na}$ początku było Słowo. J 1:1

${ }^{64}$ The text is adorned with two human figures, both of which could be representations of the Evangelist. However, scholars have suggested that only the smaller figure, shown in profile on the page's upper right-hand corner, is John, while the larger figure facing the viewer and holding a book is an anthropomorphic icon representing the Word. CH. Giddley, The Book of Kells, Del Mar 2011. http://www.arinabooks.com/uploads/2/0/7/7/20775746/_bookofkells_first_50.pdf (dostęp: 13.05. $2015 \mathrm{r}$.)

${ }^{65}$ Sullivan E., The Book of Kells, [1920], http://www.sacred-texts.com/neu/celt/bok/bok04.htm

${ }^{66}$ Wood, Celtowie - ludzie, mitologia, sztuka, s. 83. 
fantazyjnych istot, ludzi i zwierząt - ptaków, jaszczurek, psów - skręcone i splecione razem w skomplikowanych układach. Inne często występujące wzory to geometryczne motywy wstążek wiązanych w proste ornamenty przez czerwone przerywane linie.

W całej księdze uderza wielki kunszt artystów; ogromne wrażenie robią wspaniałe kompozycje i zawiłe połączenia różnych symboli i emblematów: krzyża, winorośli, smoków, ryb i węży. Rysunek aż do najdrobniejszych szczegółów zachwyca doskonałością.

\section{Błędy w tekście}

Teksty ewangelii w Księdze z Kells w pewnym stopniu różnią się od uznanej wersji. Przykładowo w Ewangelii św. Mateusza 10:34 fragment tekstu brzmi: Non veni pacem mittere, sed gaudium (Nie przyszedłem przynieść pokoju, ale radość), tymczasem powinno być: Non veni pacem mittere, sed gladium (Nie przyszedłem przynieść pokoju, ale miecz). Ze słowem gladium oznaczającym miecz pomylono słowo gaudium - radość.

W rodowodzie Jezusa w Ewangelii św. Łukasza 3:23 w sekcji zawierającej listę przodków Dawida wymieniony jest dodatkowo jeden przodek czyli zapisane jest 78 pokoleń ${ }^{67}$.

\section{Zakończenie}

Księga z Kells jest najznakomitszym dziełem spośród całej grupy manuskryptów powstałych między końcem VI a początkiem IX wieku w klasztorach Irlandii $^{68}$. Jest ono uważane za jeden z najcenniejszych i najważniejszych zabytków chrześcijaństwa irlandzkiego i dzieł sztuki iryjskiej. Jednocześnie jest uznane za najpiękniejszy średniowieczny manuskrypt europejski jaki zachował się do naszych czasów. Jego sława opiera się głównie na przepychu i artyzmie dekoracji, które nie mają sobie równych. Znakomite kompozycje wypełniające całe strony, obfitość drobnych dekoracji i misterność ornamentacji inicjałów wykorzystywanych do podkreślenia tekstu czyni Księgę z Kells jedyną i niepowtarzalną. To wszystko sprawiało, że ludzie w średniowieczu byli przekonani, że tak wspaniałe skarby musiały być dziełem aniołów, a nie ludzi.

Od połowy XVII wieku manuskrypt przechowywany jest na stałe w Bibliotece Trinity College w Dublinie, niezmiennie pod sygnaturą MS 58. Księga znajduje się w oddzielnym, niemal całkowicie zaciemnionym pomieszczeniu, tzw. Skarbcu (Treasury) i umieszczona jest w specjalnej, bezpiecznie podświetlanej gablocie.

\footnotetext{
${ }^{67}$ Większość badaczy akceptuje dzisiaj wariant 77 pokoleń. https://pl.wikipedia.org/wiki/Genealogia_Jezusa

${ }^{68}$ Do grupy tej zaliczane są także: Cathach św. Kolumby, Ambrosiana Orosius i Księga z Durrow (wszystkie z VII w.), z początku VIII wieku m.in. Ewangeliarz z Durham, Ewangeliarz z Echternach, Ewangeliarz z Lindisfarne oraz Ewangeliarz z Lichfield, zaś z końca VIII w. pochodzą Ewangeliarz z Sankt Gallen i Ewangeliarz z Macregal. Księga z Armagh, tzw. Pryscjan z Leiden oraz Pryscjan z Sankt Gallen powstały na początku IX wieku. Encyklopedia Wiedzy o Książce, szp. 2079-2080.
} 
W 1951 roku szwajcarskie wydawnictwo Urs Graf-Verlag z Berna wykonało faksymile Księgi z Kells. Większość stronic została zreprodukowana przy użyciu fotografii czarno-białej, czterdzieści osiem stron zreprodukowano w kolorze (w tym wszystkie całostronicowe ilustracje). W 1990 roku inne szwajcarskie wydawnictwo Faksimile Verlag z Lucerny opublikowało kolorowe faksymile księgi, a na początku XXI wieku w Bibliotece Trynity College powstało repozytorium cyfrowe, gdzie udostępniane są zasoby cyfrowe biblioteki. Pierwsza cyfrowa edycja Księgi z Kells jest firmowana przez UNICEF (The Book of Kells CD ROM) ${ }^{69}$. W początkach 2. dekady XXI wieku Trinity College Dublin udostępnił całość dzieła w swojej witrynie internetowej (http://digitalcollections.tcd.ie/home/index. php?DRIS_ID=MS58_003v). Powstały także komercyjne prezentacje (aplikacje), przeznaczone dla urządzeń mobilnych.

Księga z Kells stała się sławna i popularna na całym świecie, osiągając status symbolu bogactwa wielowiekowej chrześcijańskiej kultury i tradycji Irlandii ${ }^{70}$. W roku 2011 dzieło zostało wpisane na listę UNESCO Pamięć Świata ${ }^{71}$.

Wykaz stron (folio) opisanych w tekście $1 \mathrm{r}$ - lista nazw hebrajskich i symbole czterech Ewangelistów 2r-6r - ozdobne tablice Kanonów Euzebiusza $6 \mathrm{v}-7 \mathrm{r}$ - notatki dotyczące ziem będących w posiadaniu klasztoru $7 \mathrm{v}$ - Matka Boska z Dzieciątkiem i Aniołami 8r - ozdobny tekst Mt 1:18 De nativitate Christi in Bethlehem $8 \mathrm{r}-12 \mathrm{v}-$ Breves Causae do Ewangelii św. Mateusza 13r-19r - Breves Causae i Argumenta do Ewangelii św. Marka $19 \mathrm{v}-25 \mathrm{v}$ - Argumenta i Breves Causae do Ewangelii św. Łukasza i św. Jana $25 \mathrm{r}-26 \mathrm{v}$ - lista imion hebrajskich

$26 \mathrm{r}$ - notatki dotyczące klasztoru $27 \mathrm{v}$ - symbole czterech ewangelistów $28 \mathrm{r}$ - strona niezapisana $28 \mathrm{v}-$ portret św. Mateusza 29r - ozdobny inicjał incipitu Ewangelii św. Mateusza 1:1, tzw. Liber generationis $32 \mathrm{r}$ - strona niezapisana 32v - wizerunek Chrystusa Króla, Maiestas Domini

\footnotetext{
${ }^{69} \mathrm{http}: / /$ digitalcollections.tcd.ie/home/\#searchresults oraz https://www.tcd.ie/Library/bookofkells/

${ }^{70}$ Book of Kells www.unesco.org. (dostęp: 08. 05. 2015 r.)

${ }^{71}$ Pamięć Świata (Memory of the World International Register) - międzynarodowy projekt sygnowany przez UNESCO, zapoczątkowany w 1992 roku, którego celem jest podejmowanie działań służących zachowaniu, ratowaniu i udostępnianiu dokumentów: rękopisów, druków, inskrypcji, dokumentów audiowizualnych (nagrań i filmów), itp. o światowym znaczeniu historycznym lub cywilizacyjnym. https://pl.wikipedia.org/wiki/Pami\%C4\%99\%C4\%87_\%C5\%9Awiata\#Irlandia_.281.29 (dostęp: 05.08.2015 r.)
} 
$33 r$ - ilustracja tzw. „kobierzec”

$33 \mathrm{v}$ - strona niezapisana

34r - Chi Rho ozdobny monogram znany jako „monogramem Wcielenia”

40v - osiem błogosławieństw św. Mateusza 5:3-10

$114 \mathrm{r}$ - scena pojmania Chrystusa

$114 \mathrm{v}$ - dekorowane zdanie: Tunc dicit illis IHS omnes vos scan

$123 \mathrm{v}$ - strona niezapisana

124r - ozdobne zdanie w Ewangelii św. Mateusza 27:38 Tunc crucifixerant XPI

cum eo duos latrones

$128 \mathrm{v}$ - koniec Ewangelii św. Mateusza

$129 \mathrm{r}$ - strona niezapisana

$129 \mathrm{v}-$ symbole czterech Ewangelistów

130r - ozdobny inicjał incipitu Ewangelii św. Marka Initium Evangelium Iesu XPI

Filii Dei

183r - ozdobny tekst w Ewangelii św. Marka 15:25 Erat autem hora tertia

$187 \mathrm{v}$ - koniec Ewangelii św. Marka 16:19-20 Wniebowstąpienie

188r - ozdobny inicjał Quoniam

$188 \mathrm{v}$ - ozdobny inicjał incipitu Ewangelii św. Łukasza 1:5 Fuit diebus Herodis

200r-202r - rodowód Jezusa Ewangelia św. Łukasza 3:26-38

$202 \mathrm{v}$ - kuszenie Jezusa

203r - ozdobne zdanie 4:1 IHS autem plenus SB SSCO regressus

285r - ozdobne zdanie 24:1 Una autem sabbati valde dilu

$289 \mathrm{v}$ - notatki dotyczące klasztoru

$290 \mathrm{v}$ - symbole czterech Ewangelistów

$291 \mathrm{r}$ - strona niezapisana

$291 v$ - portret św. Jana Ewangelisty

$292 \mathrm{r}$ - ozdobny inicjał incipit Ewangelii wg św. Jana 1:1 In principio erat verbum $340 \mathrm{v}$ - ostatnia strona księgi dotyczy Ewangelii św. Jana do 17:13

słowa kluczowe: średniowieczny rękopis, irlandzki rękopis, Księga z Kells, Ewangeliarz z Kells, Opactwo Kells, Trinity College Dublin, mnisi irlandzcy na Iona, iluminowany rękopis w VIII lub na początku IX wieku 


\section{BIBLIOGRAFIA}

The Annals of Ulster, p. 437, http://www.ucc.ie/celt/published/T100001A/ http://biblia.deon.pl/

Bulas Ryszarda, Irlandia między epoką kamienia a średniowieczem, Poznań 2000

Dahl Sven, Dzieje książki, Wrocław 1965

Diehl Edith, Bookbinding, Vol. 2, New York 1980

Dillon Myles, Chadwick Nora K., Ze świata Celtów, Warszawa 1975

Encyclopedia International, T.3, New York 1969

Encyklopedia Katolicka, red. B. Migut, T.4, Lublin 1983

Encyklopedia Wiedzy o Książce, red. A. Birkenmajer, B. Kocowski, J. Trzynadłowski, Wrocław 1971

Giddley Charles, The Book of Kells, Del Mar 2011 http://www.arinabooks.com/ uploads/2/0/7/7/20775746/_bookofkells_first_50.pdf

Gieysztor Aleksander, Zarys dziejów pisma łacińskiego, Warszawa 1973

Głombiowski Karol, Szwejkowska Helena, Książka rękopiśmienna i biblioteka w starożytności i średniowieczu, Warszawa 1987

Haywood John, Celtowie od epoki Brązu do New Age, Warszawa 2008

http://digitalcollections.tcd.ie/home/index.php?DRIS_ID=MS58_003v

https://en.wikipedia.org/wiki/Book_of_Kells

https://en.wikipedia.org/wiki/Roger_Powell_\%28bookbinder\%29

https://pl.wikipedia.org/wiki/Ksi\%C_4\%99ga_z_Kells

Jaworska Agnieszka B., Anglo-iryjska szkoła iluminatorska w: Wirtualna historia książki i bibliotek, Kraków 2002 http://www.wsp.krakow.pl/whk/konkurs/szkola.html

Księga imion i świętych, oprac. H. Fros, F. Sowa, T.3, Kraków 1998

Lissowska Agnieszka, Wczesnośredniowieczne iluminatorstwo iryjskiej, „Polonia Christiana", 5 (2008)

Low Mary, Celtic Christianity and Nature, Edinburgh 1996

Maier Bernhard, Dictionary of Celtic Religion and Culture, Woodbridge 2000

Nordenfalk Carl, Celtic and anglo-saxon painting. Book illumination in the british isles 600-800, London 1982

Ó Cróinín, Dáibhí, Irlandia średniowieczna: (400-1200), Warszawa 2010

Panuś Kazimierz, Święty Patryk, Kraków 2004

Semkowicz Władysław, Paleografia łacińska, wyd. II, Kraków 2002

Strzelczyk Jerzy, Iroszkoci w kulturze średniowiecznej Europy, Poznań 2008

Sullivan Edward, The Book of Kells http://www.sacred-texts.com/neu/celt/bok/bok04. htm

Wood Juliette, Celtowie - Ludzie, mitologia, sztuka, Warszawa 2002

www.arinabooks.com/uploads/2/0/7/7/20775746/_bookofkells_first_50.pdf 


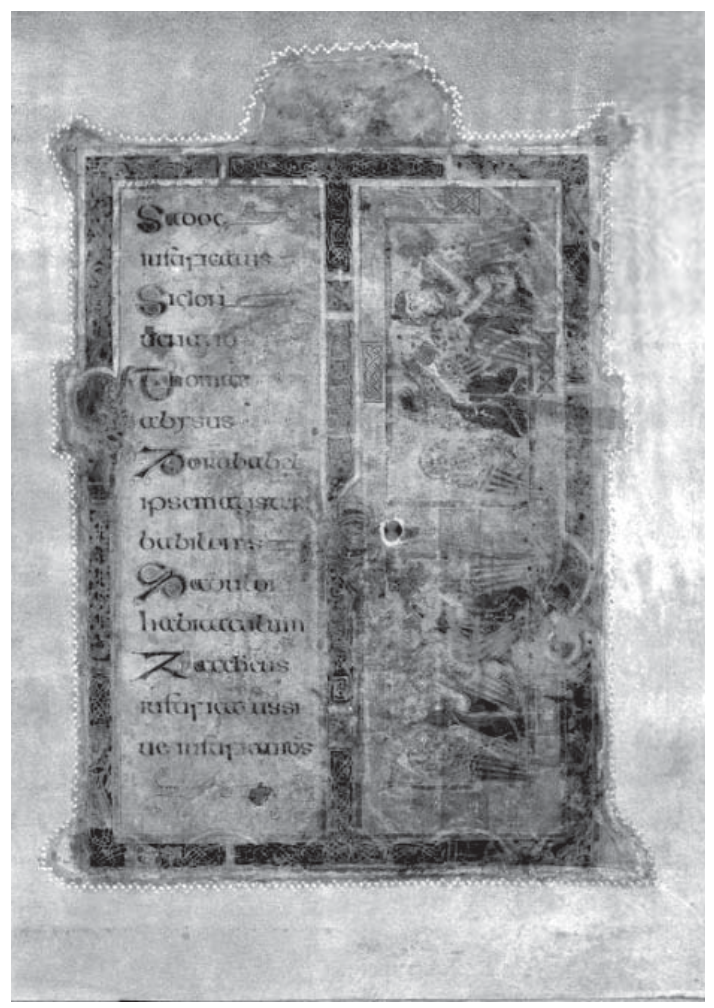

Fot. 1. 1.Pierwsza strona (f.1r)

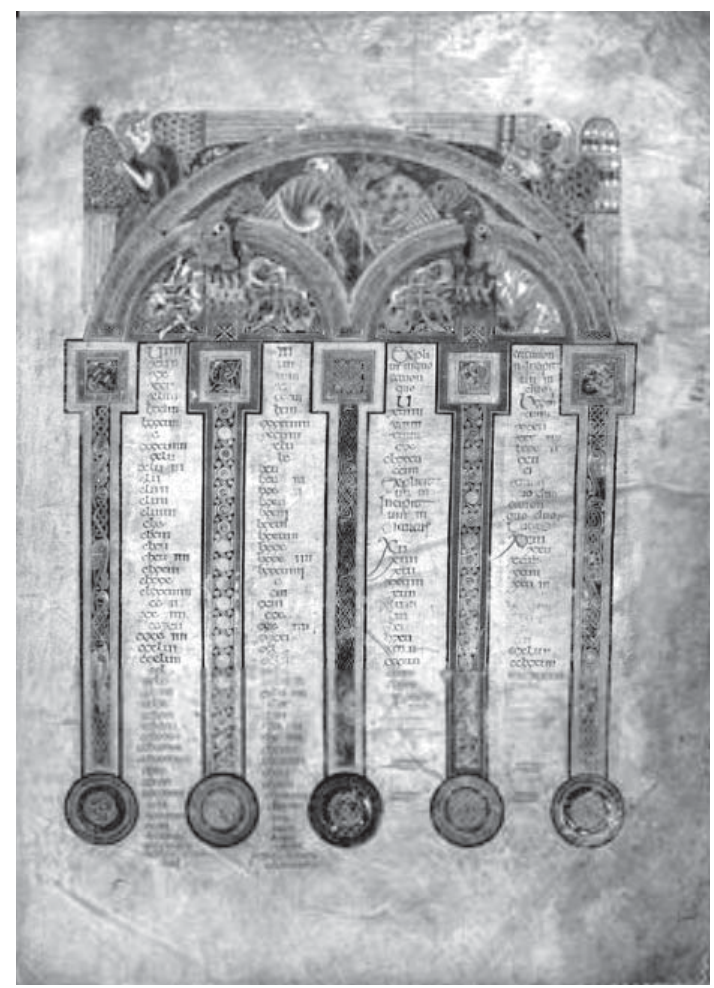

Fot. 3. Tablice Kanonów VI, VII, VIII (f.5r)

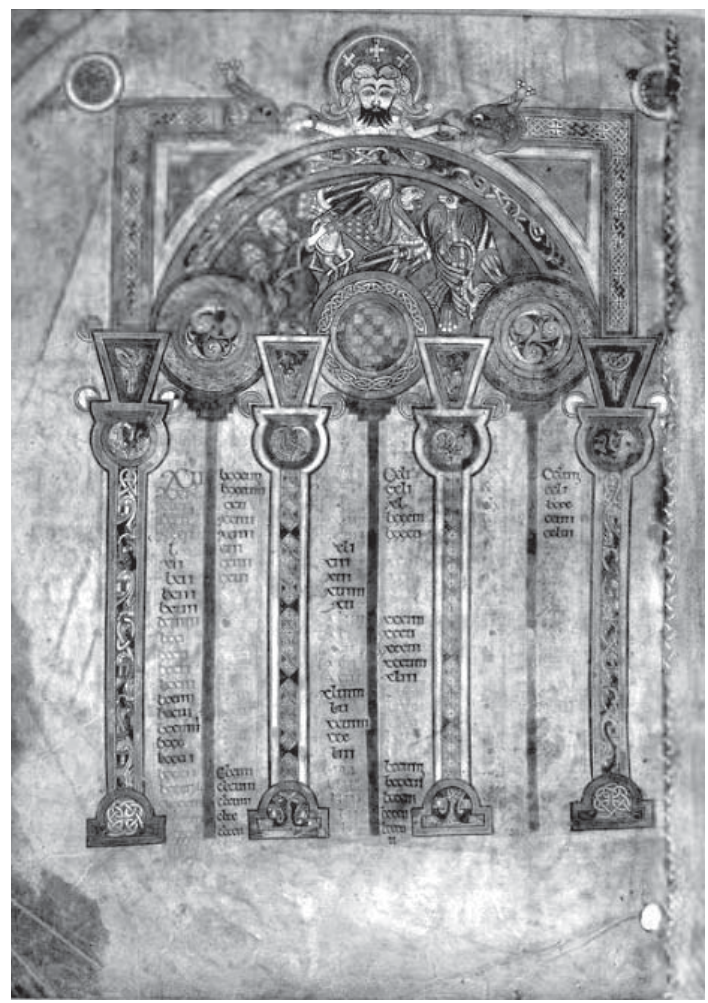

Fot. 2. Tablice Kanonu II (f.2v)

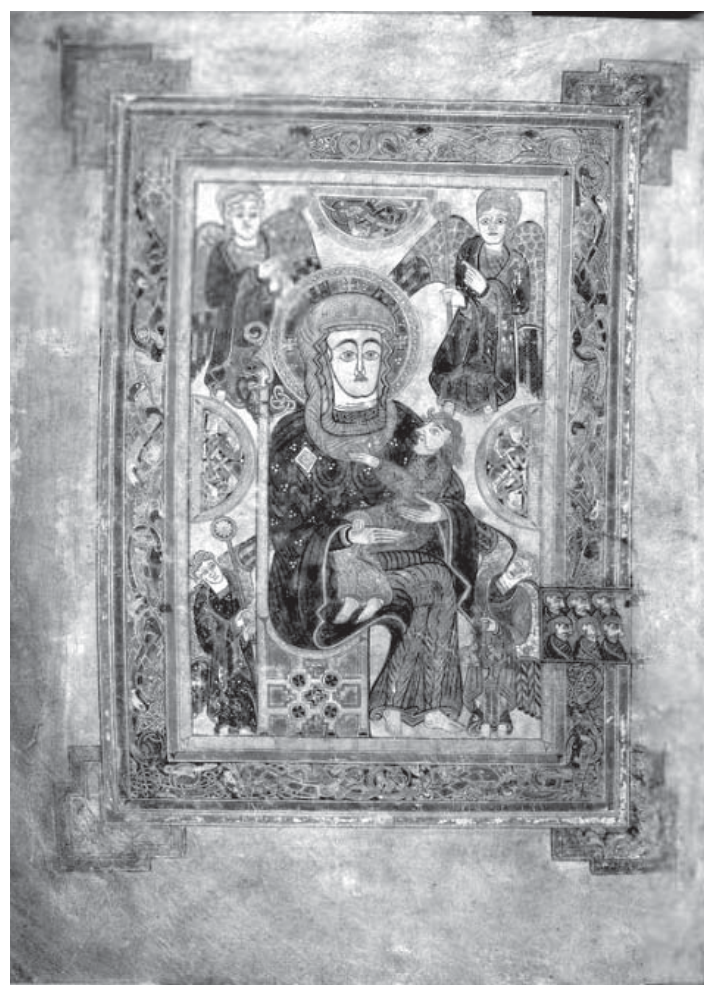

Fot. 4. Matka Boska z Dzieciątkiem i Aniołami (f. $7 \mathrm{v}$ ) 


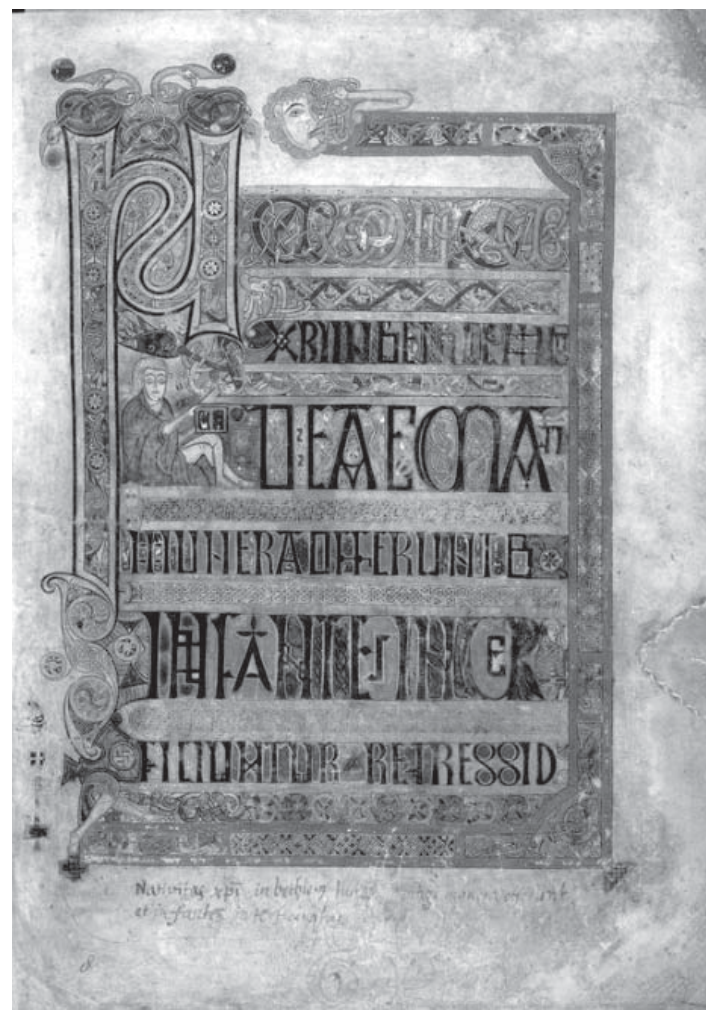

Fot. 5. Breves i Argumenta dla św. Mateusza: Nativitas XPI in Bethlehem Judaea (f.8r)

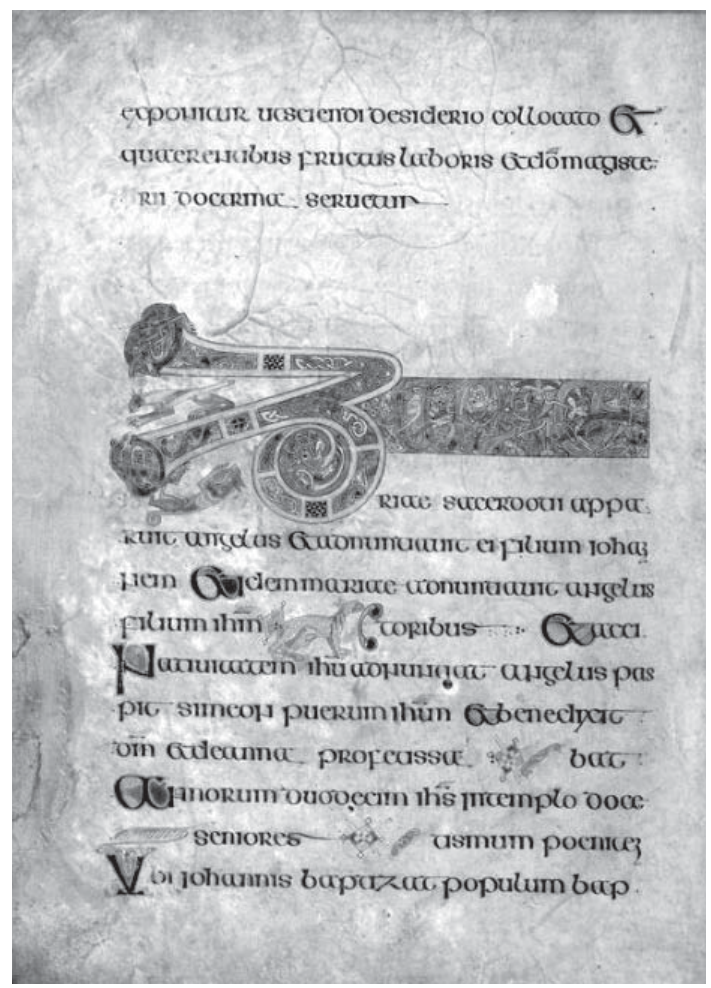

Fot. 7. Breves Causae i Argumenta do Ewangelii św. Marka (f.19v)

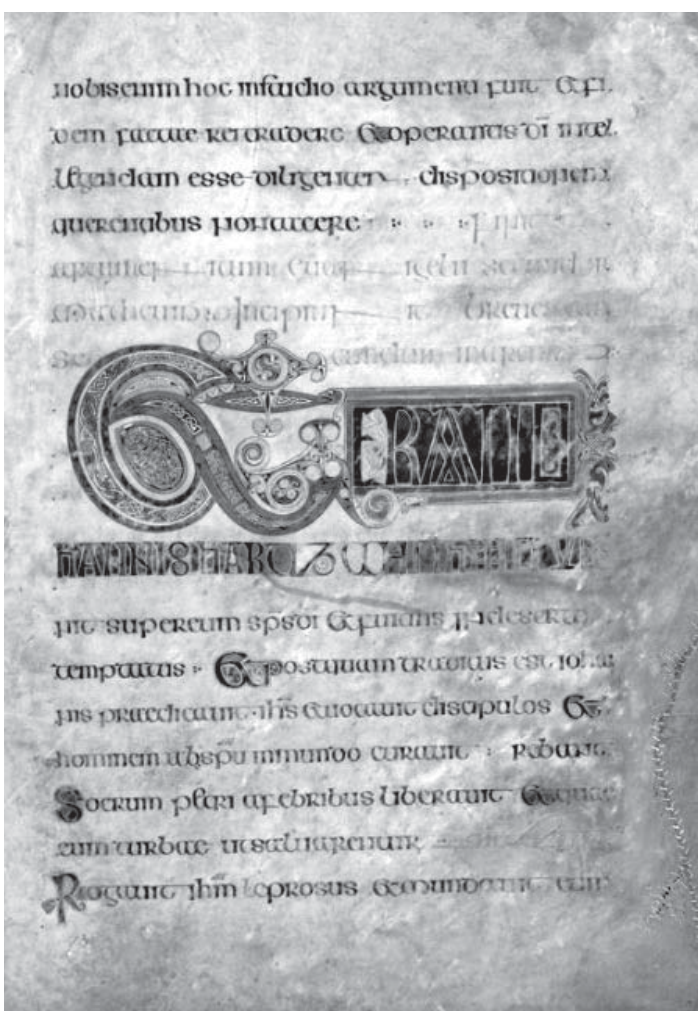

Fot. 6. Breves causae i Argumenta do Ewangelii św. Marka (f.13v)

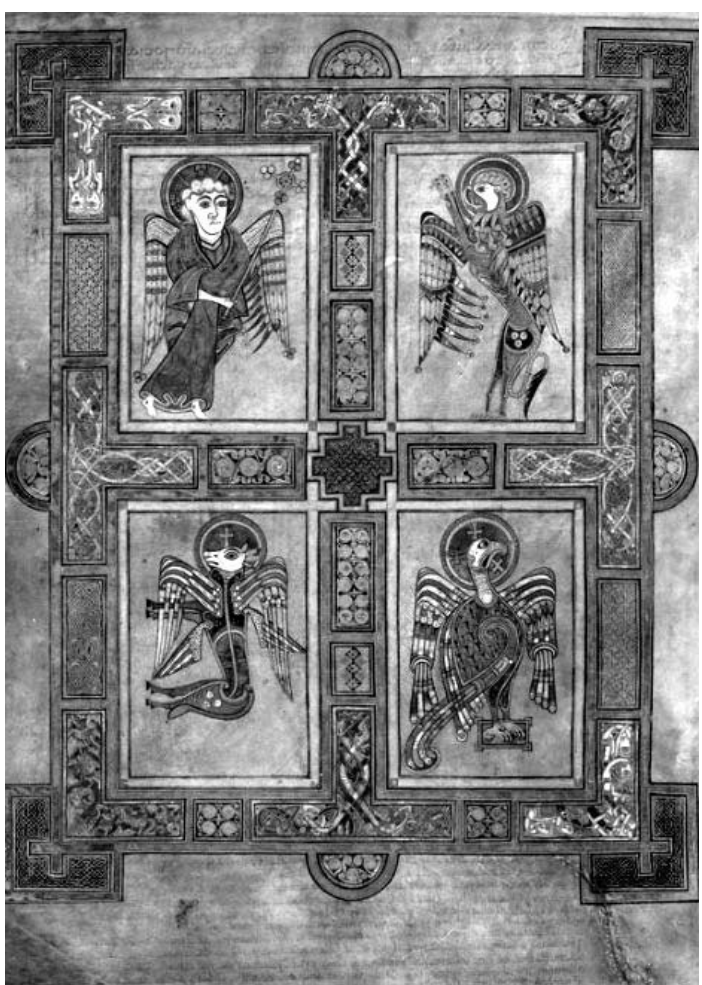

Fot. 8. Symbole czterech ewangelistów $(\mathrm{f} .27 \mathrm{v})$ 


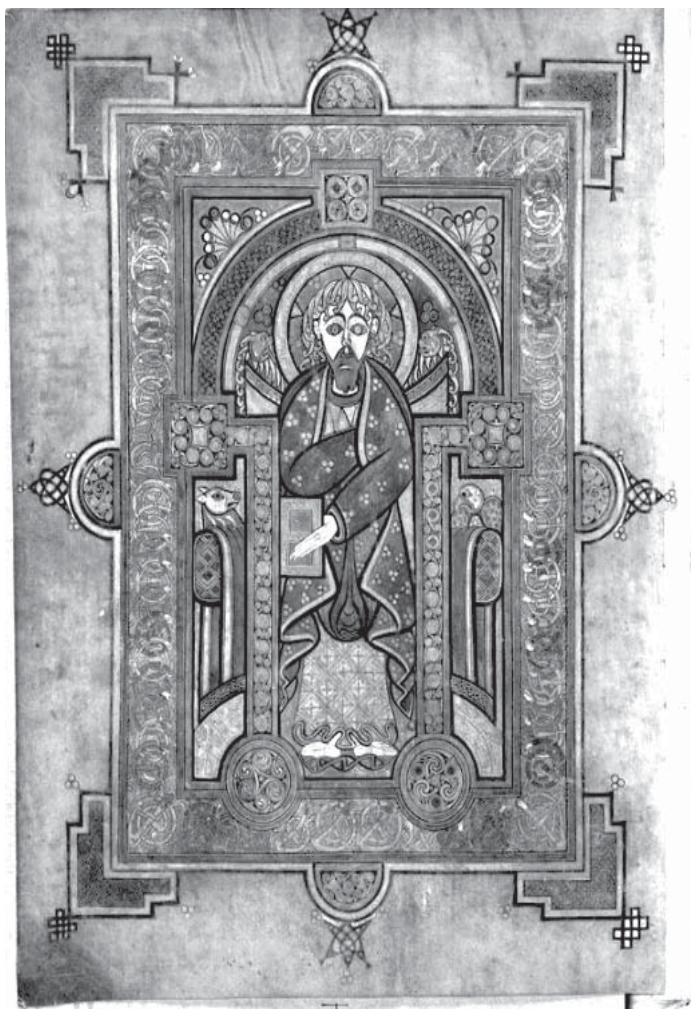

Fot. 9. Portret św. Mateusza (f.28v)

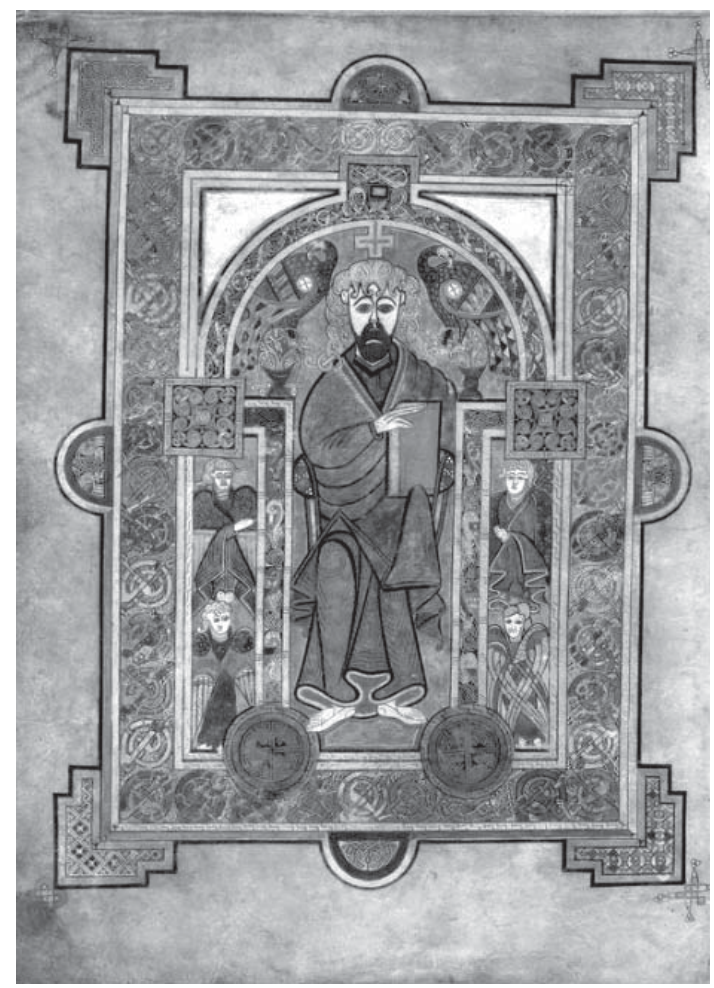

Fot. 11. Wizerunek Chrystusa Króla - Maiestas Domini (f.32v)

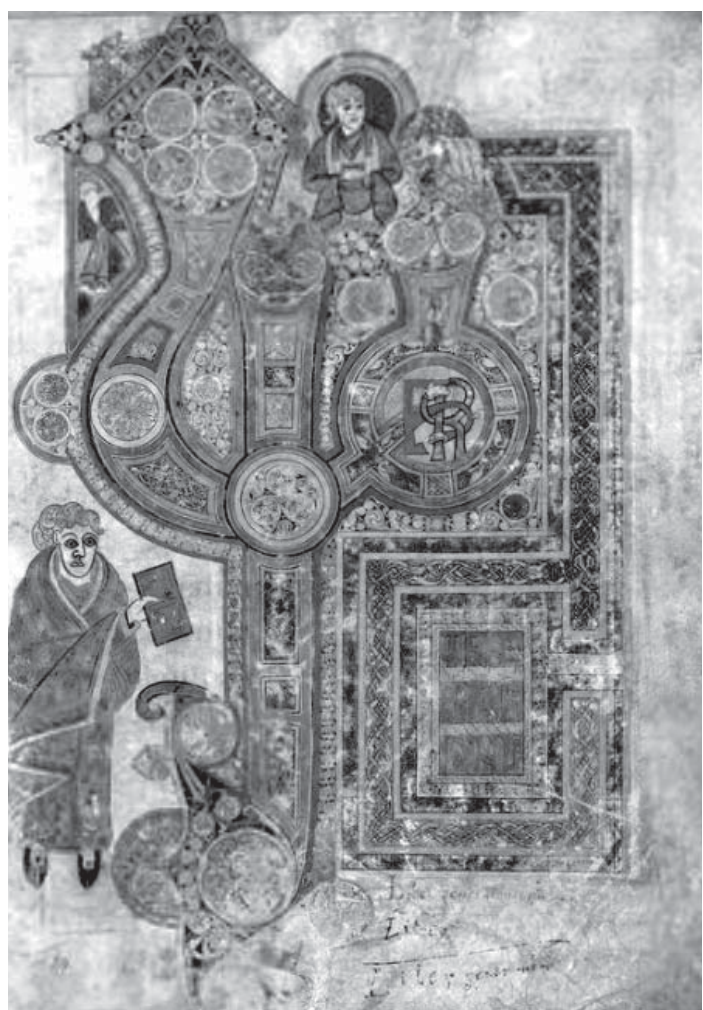

Fot. 10. Ozdobny inicjał w Ewangelii św. Mateusza Liber generationis (f.29r)

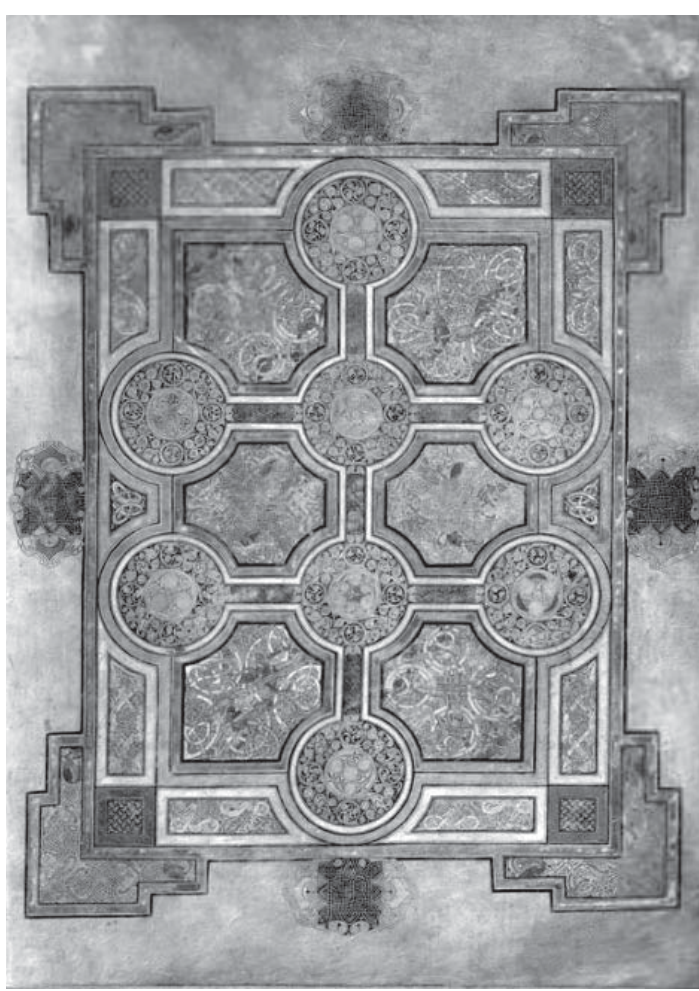

Fot. 12. Strona „kobierzec” (f.33r) 


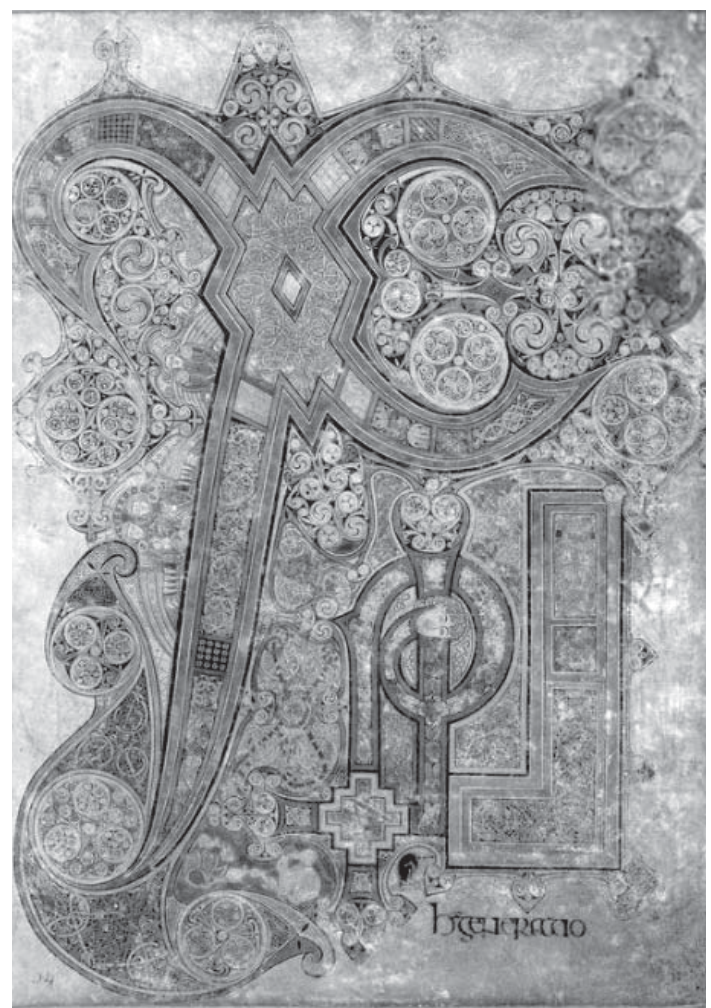

Fot. 13. Chi Rho ozdobny monogram znany jako „monogramem Wcielenia” (f.34r)

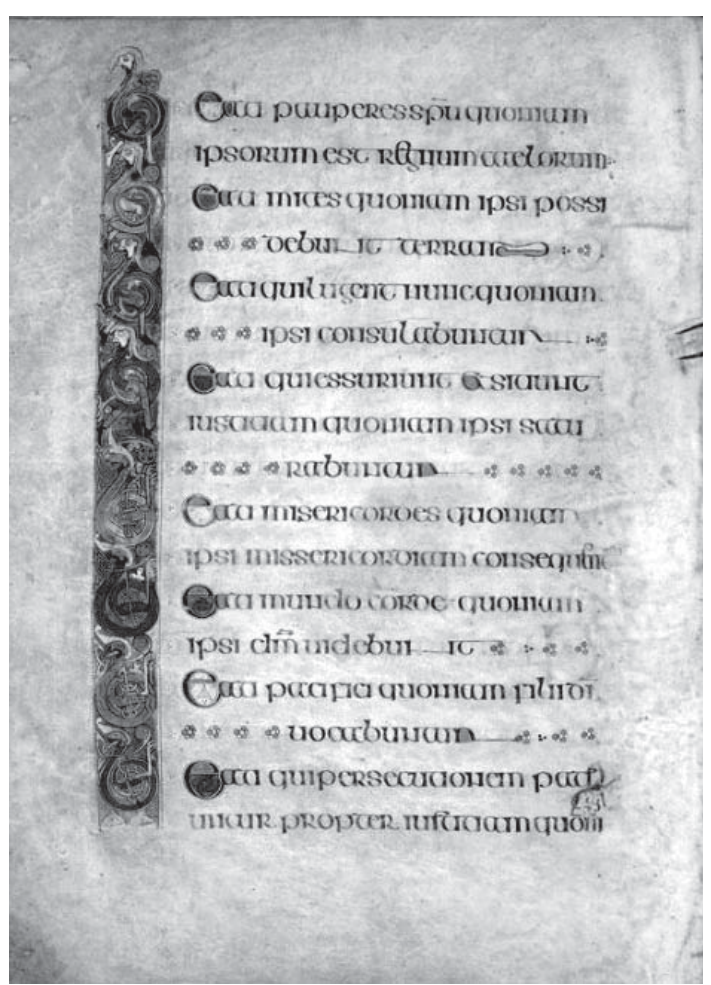

Fot. 15. Osiem błogosławieństw św. Mateusza (f.40v)

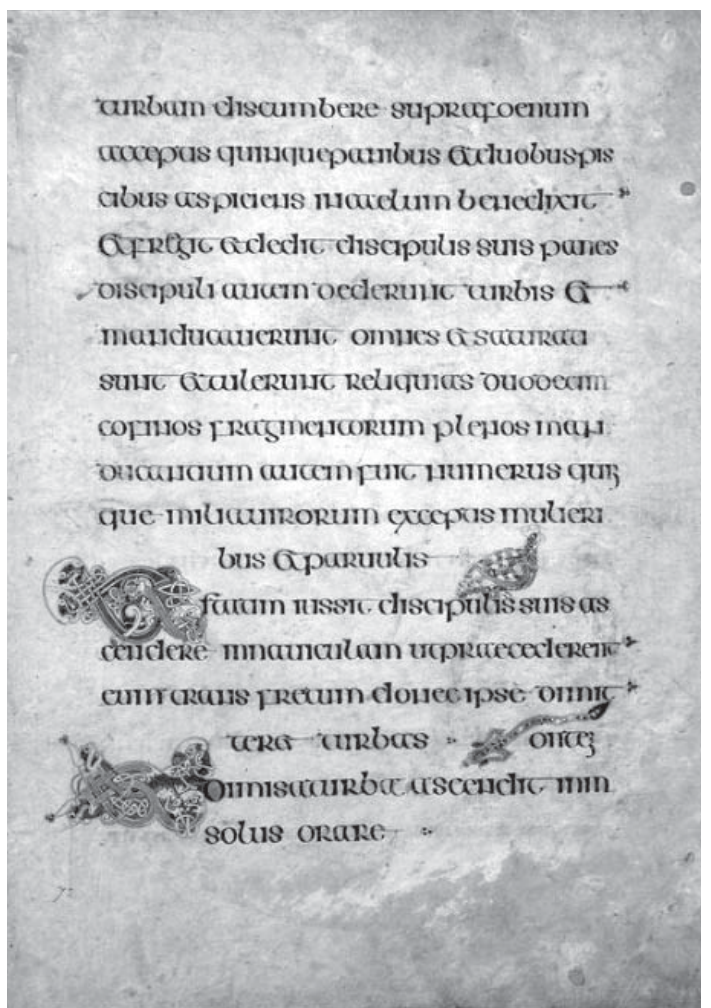

Fot. 14. Małe inicjały, jaszczurka i paw (f.72r)

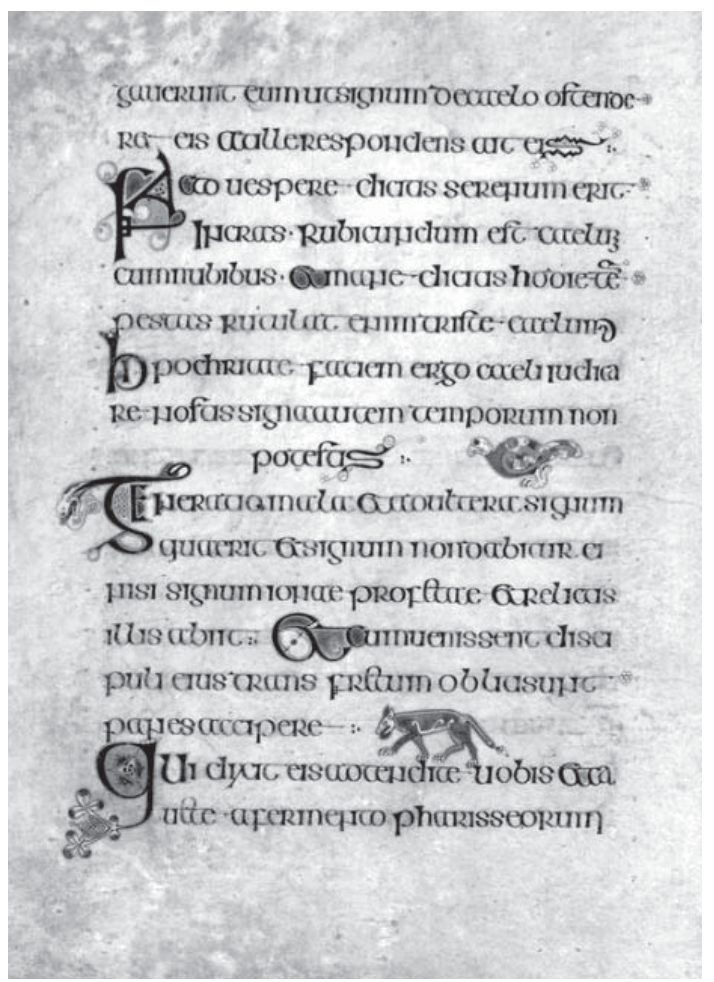

Fot. 16. Małe inicjały, pies i ptak (f.76v) 


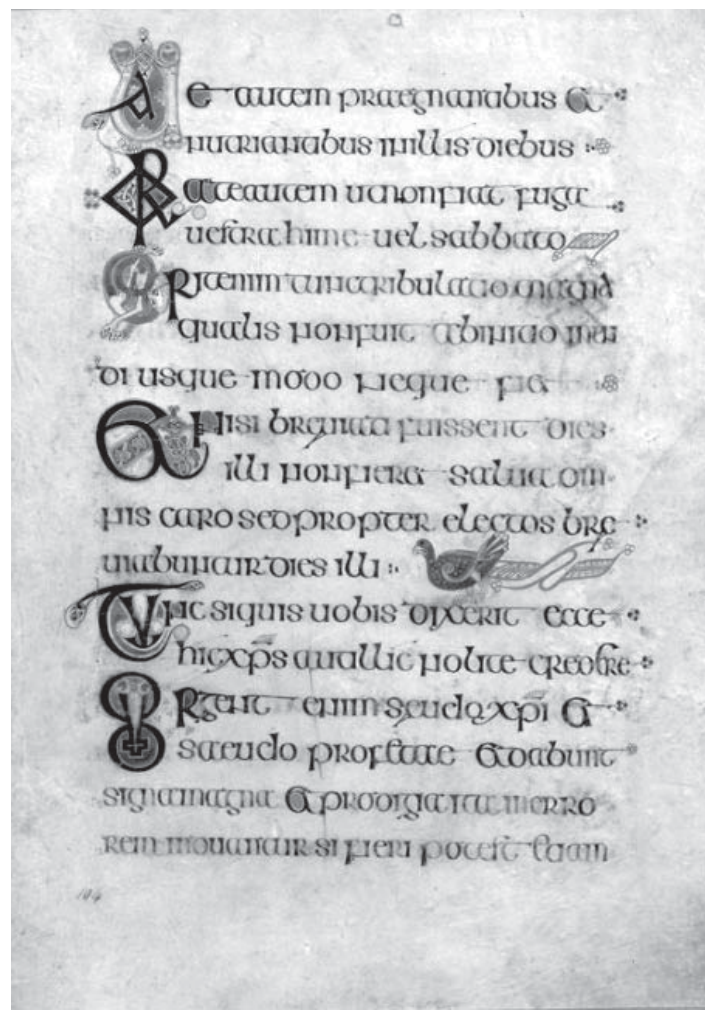

Fot. 17. Małe inicjały, paw i kwiatuszki (f.104r)

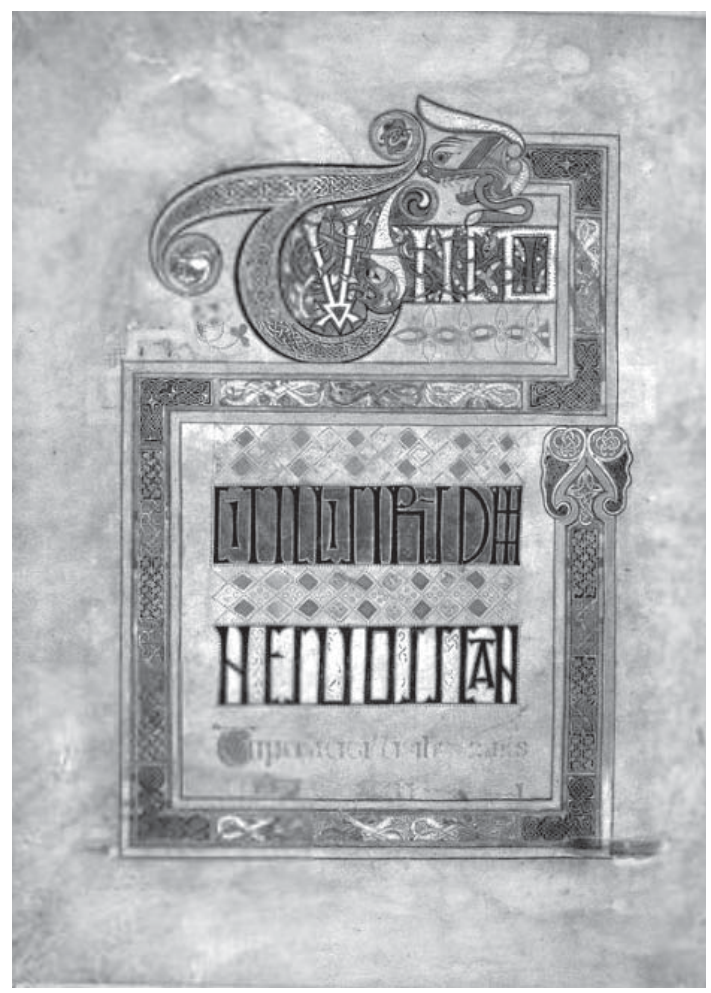

Fot. 19. Ozdobne zdanie w Ewangelii św. Mateusza: Tunc dicit illis IHS omnes vos scan $[$ dalum $](\mathrm{f} .114 \mathrm{v})$

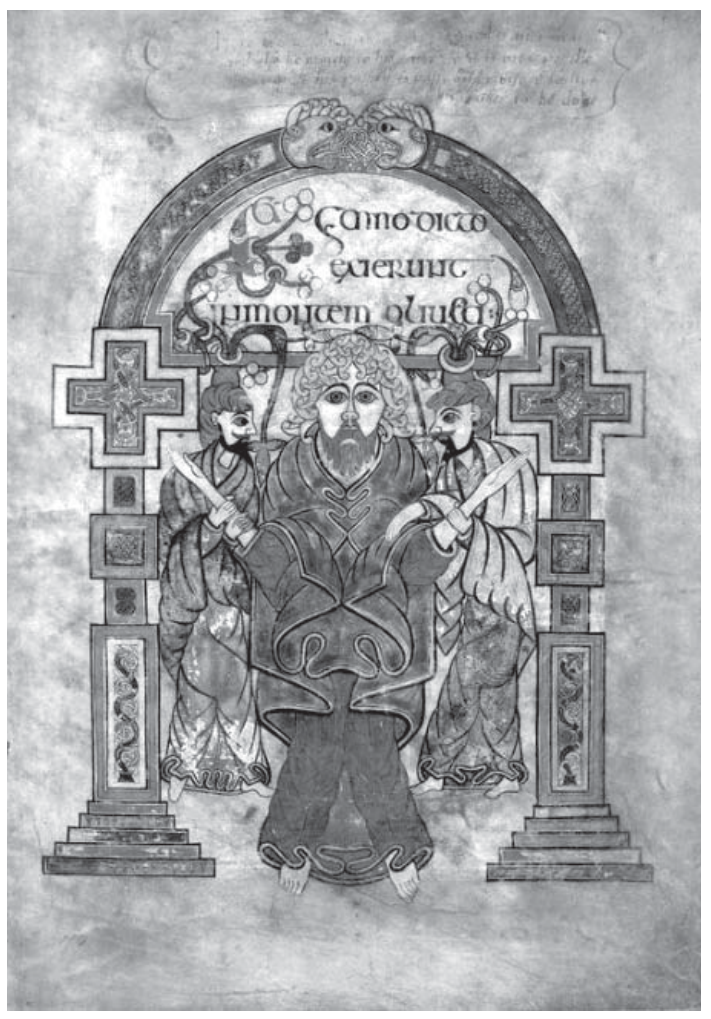

Fot. 18. Scena pojmania Chrystusa (f.114r)

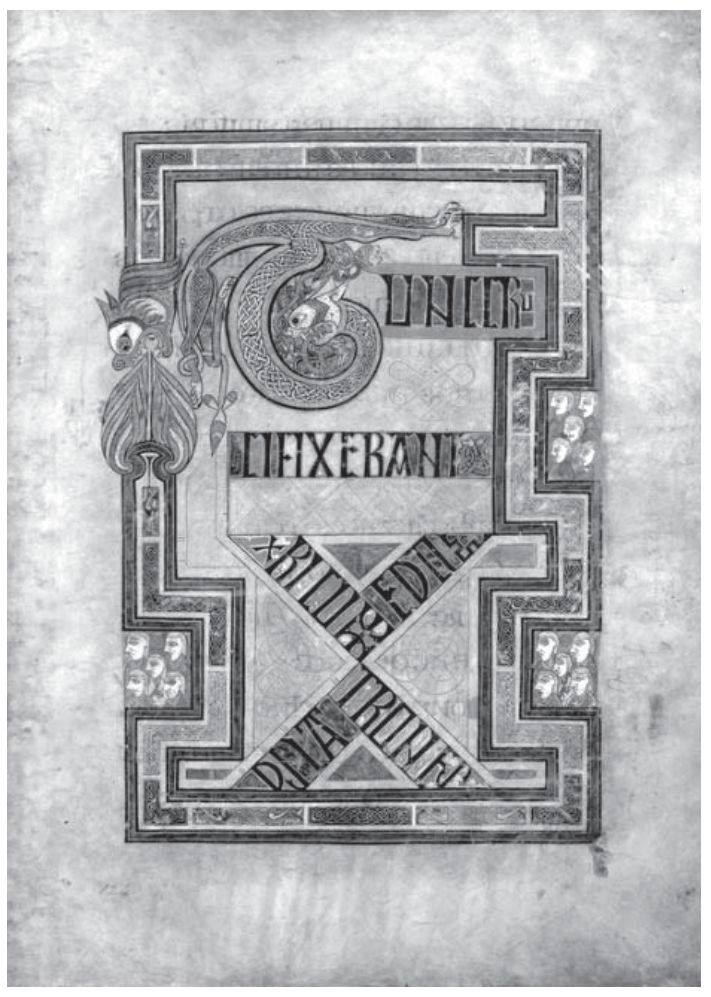

Fot. 20. Ozdobne zdanie w Ewangelii św. Mateusza: Tunc crucifixerant XPI cum eo duos latrones (f.124r) 


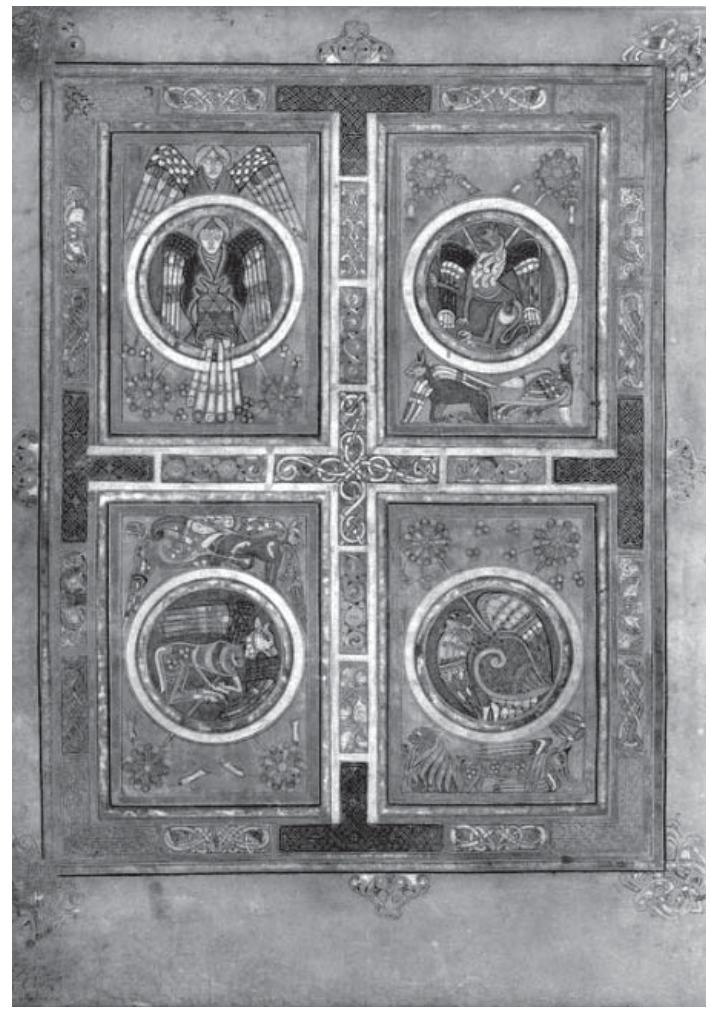

Fot 21. Symbole czterech Ewangelistów (f.129v)

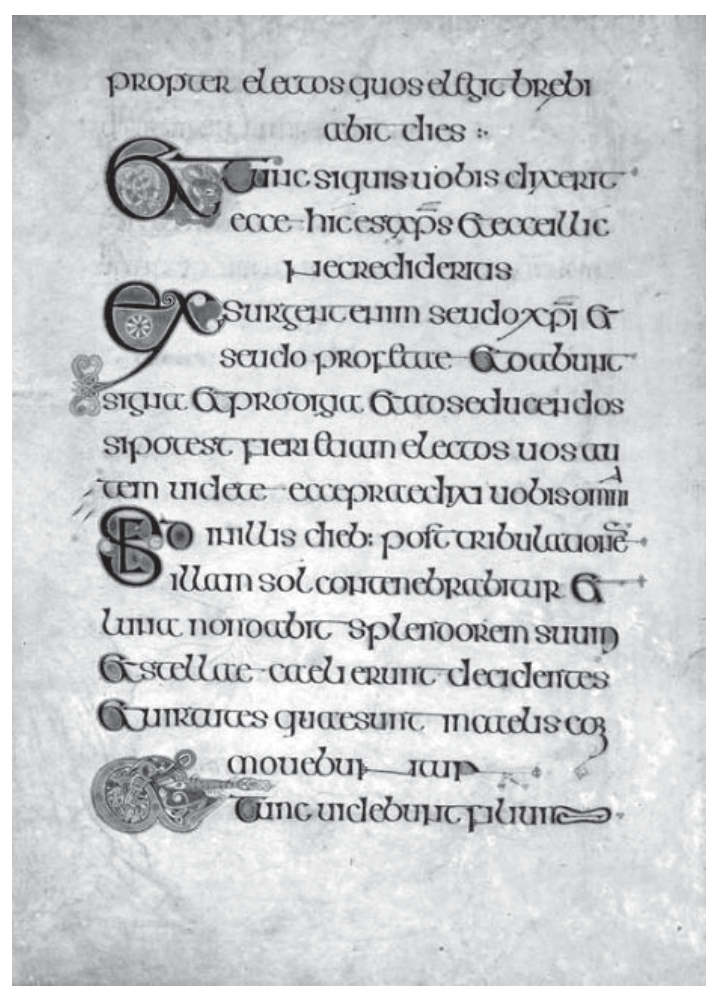

Fot. 23. Małe inicjały (f.173v)

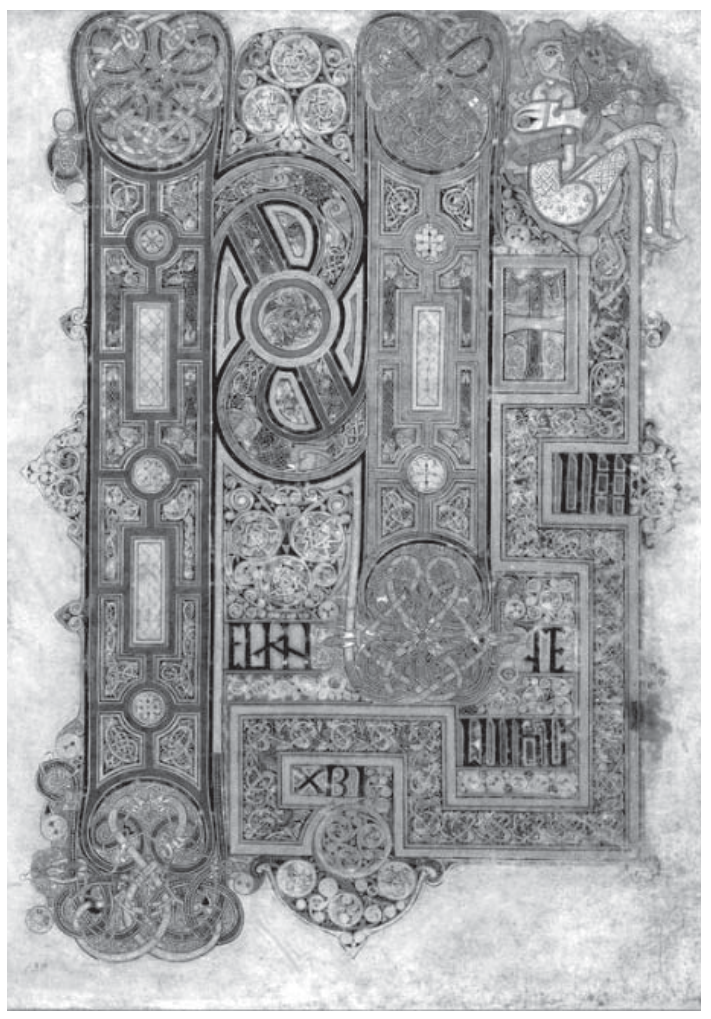

Fot. 22. Ozdobny początek Ewangelii św. Marka: Initium Evangelium Iesu XPI Filii Dei (f.130r)

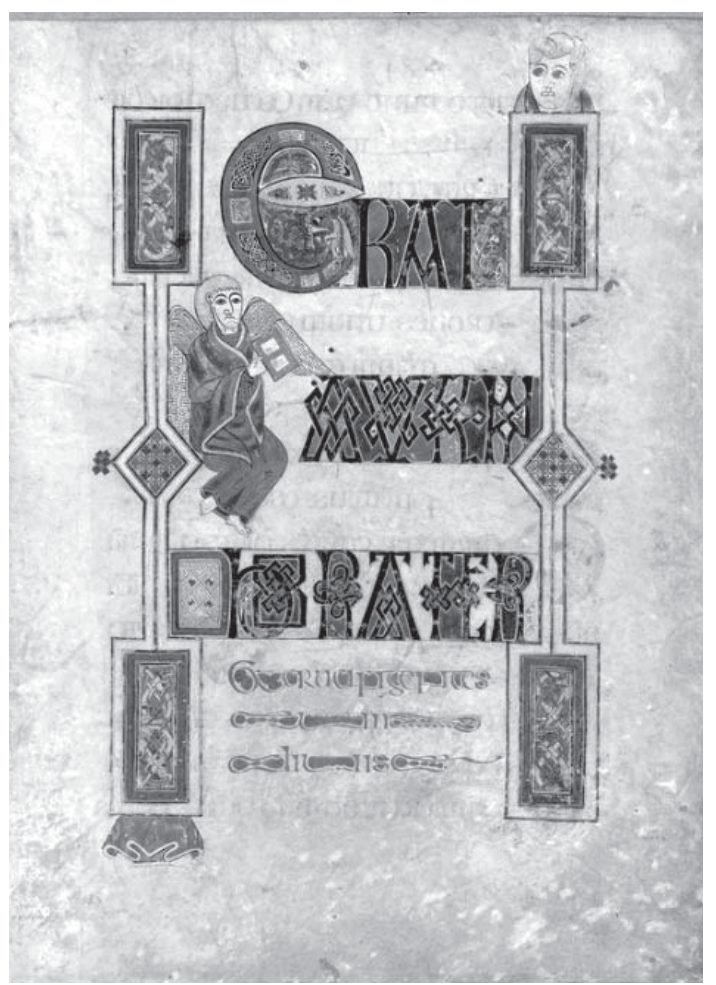

Fot. 24. Ozdobne zdanie w Ewangelii św. Marka: Erat autem hora tertia (f.183r) 


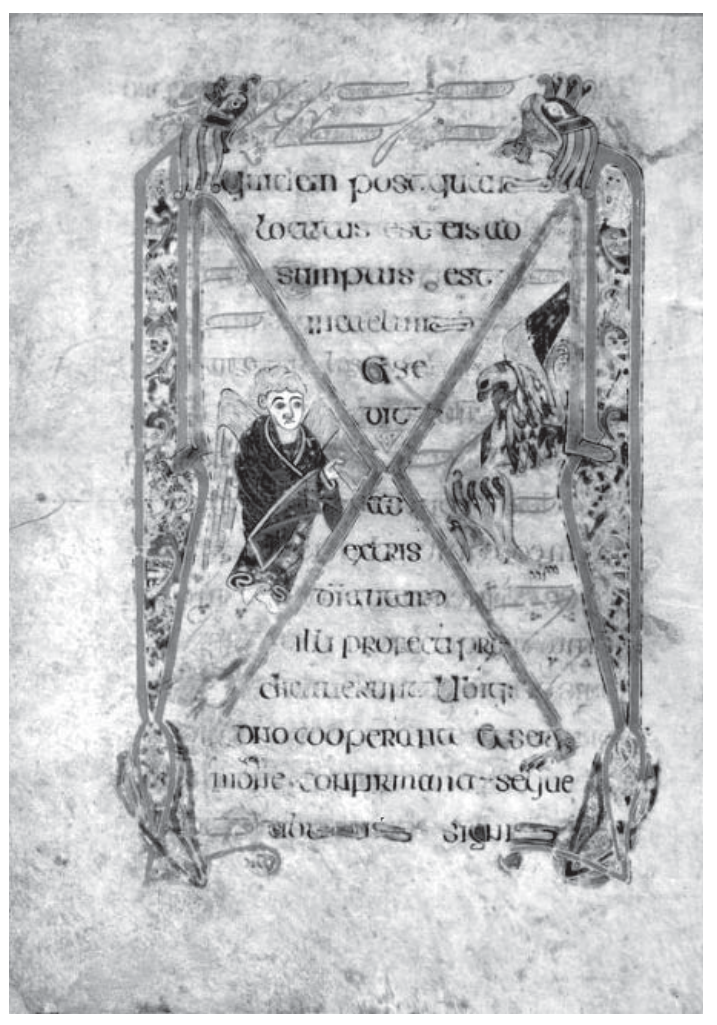

Fot. 25. Wniebowstąpienie (f.187v)

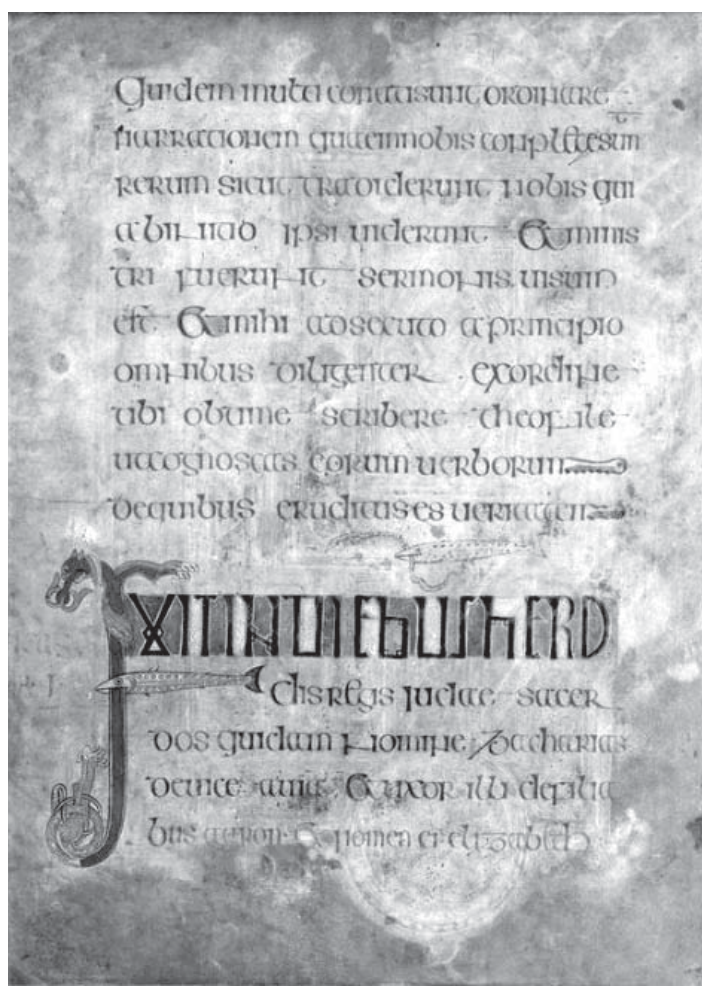

Fot. 27. Ozdobny inicjał początku Ewangelii św. Łukasza: Fuit diebus Herodis (f.188v)

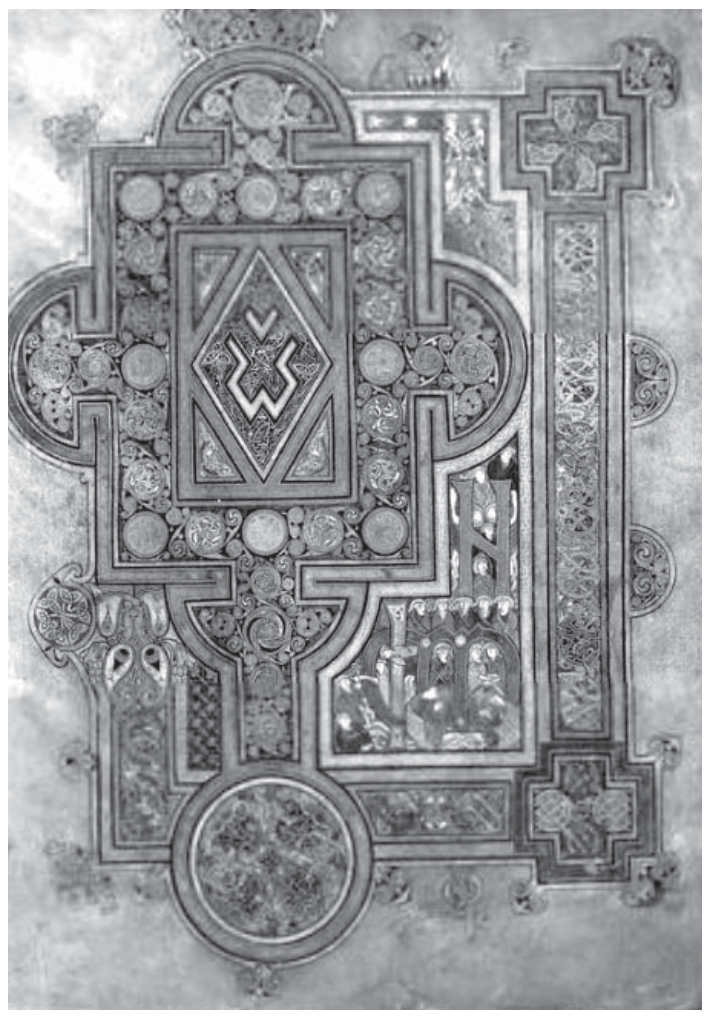

Fot. 26. Ozdobny inicjał w Ewangelii św. Łukasza: Quoniam (f.188r)

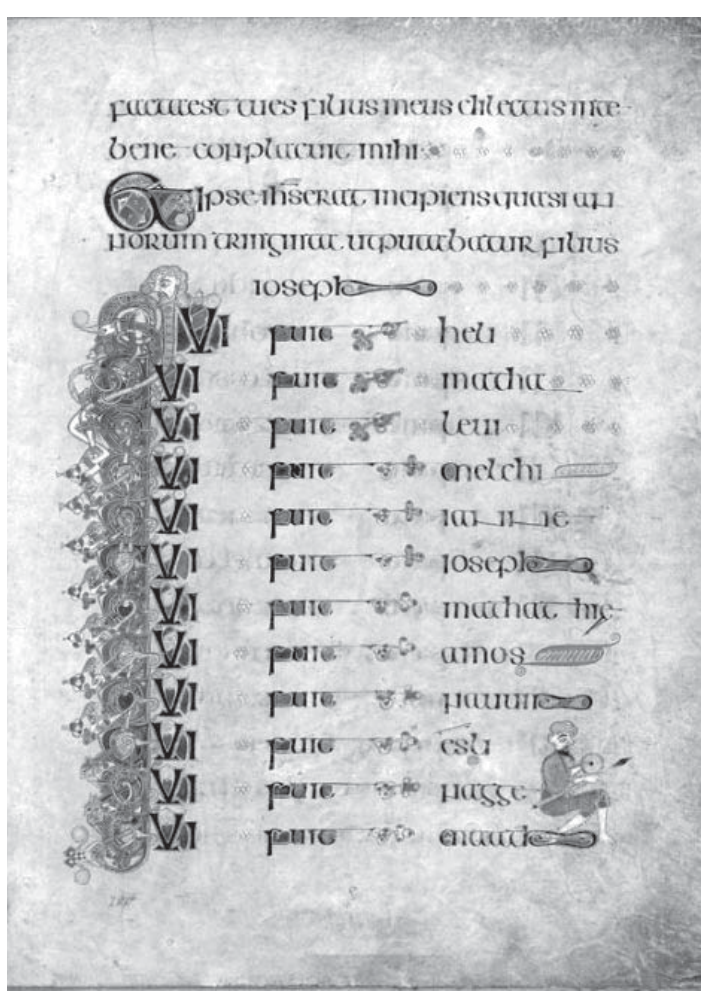

Fot. 28. Początek rodowodu Jezusa w Ewangelii św. Łukasza (f.200r) 


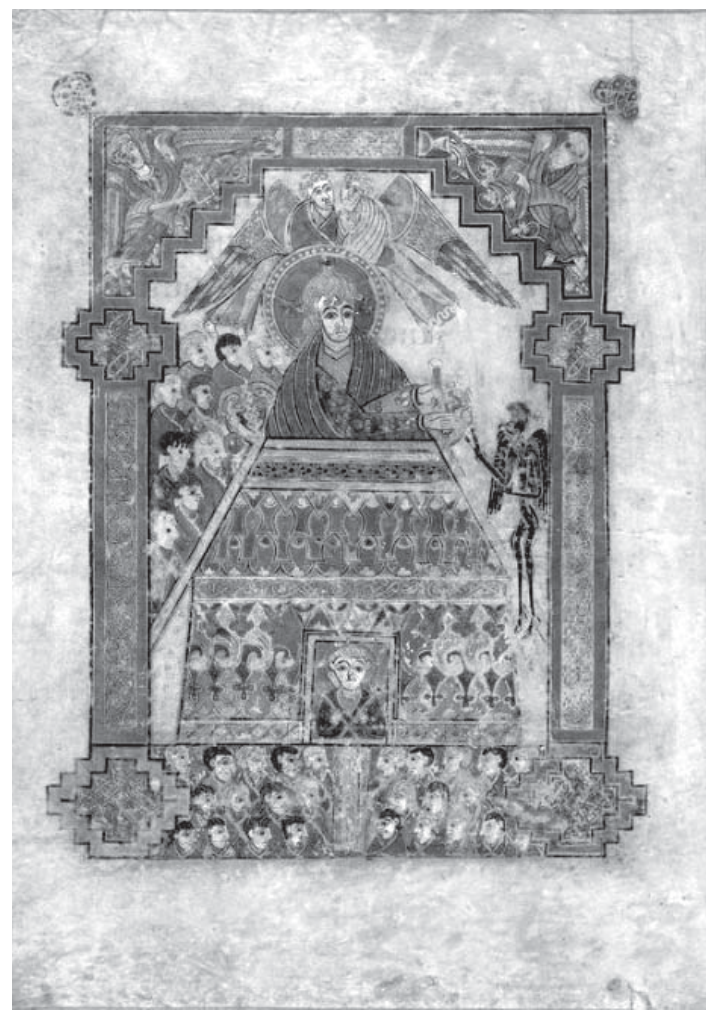

Fot. 29. Kuszenie Chrystusa (f.202v)

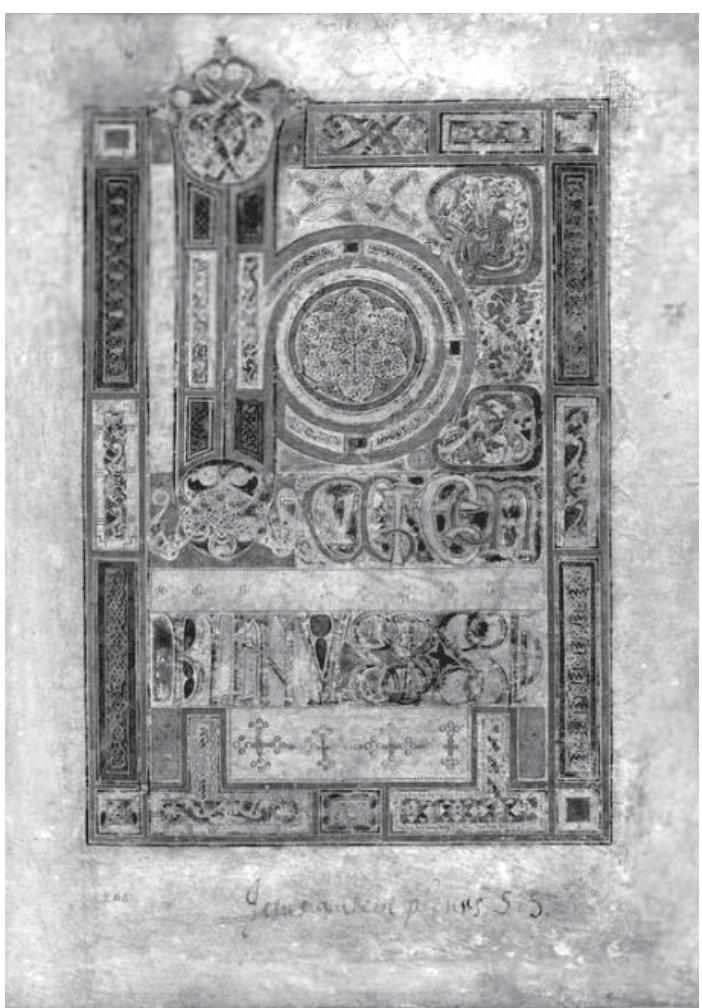

Fot. 30. Ozdobne zdanie: IHS autem plenus SB SSCO regressus (f.203r)

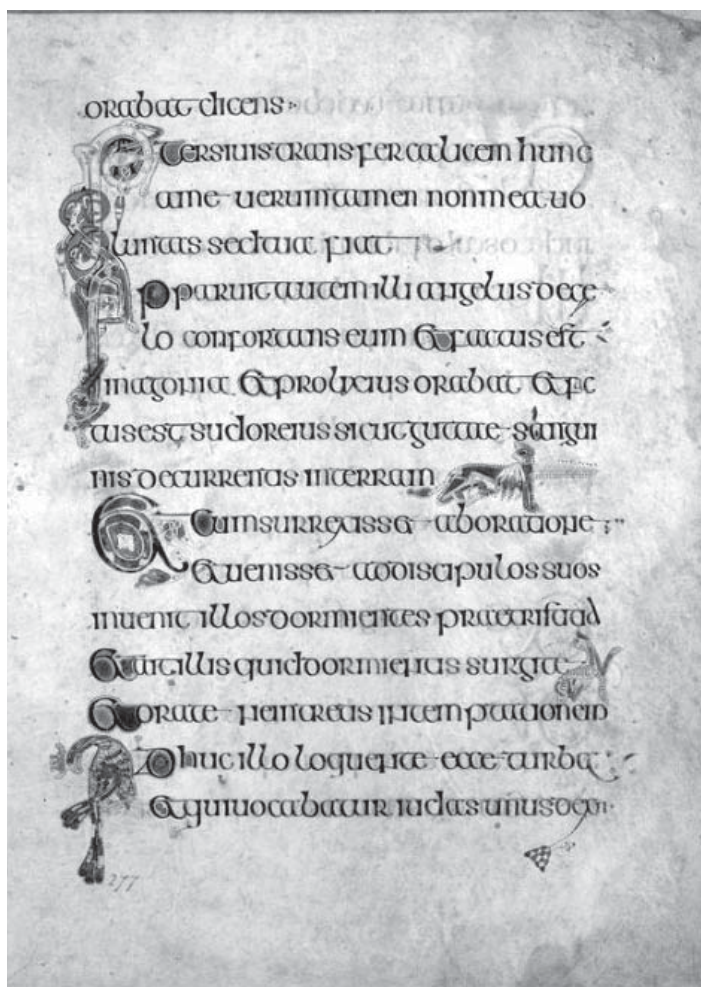

Fot. 32. Małe inicjały, gryf, paw i pies (f.277r)
Fot. 31. Małe inicjały i ryby (f.261r)

GunG llisecoe ascenomus herusol mun Gconsummabunark ompia gucrescripucsurt perproffius oep Lo hommisarodfur eanm gerrabus . amludtur aplagllabrar acon. 1. spular gpofi guanflagillauerm. ocadert eum aceracore- Rfsurgo - (5) am abeas amoumbellegebur quace forcebunum.

- Cumesc curcencumcopropmqud Ser Re hendho cocous guidumse

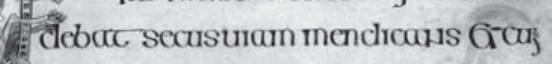
cudire curbum pralter eumcem micr Roscubuc guidhocesse dpocruncaucg

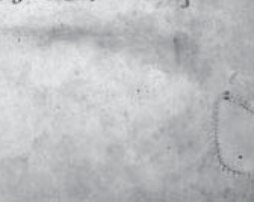




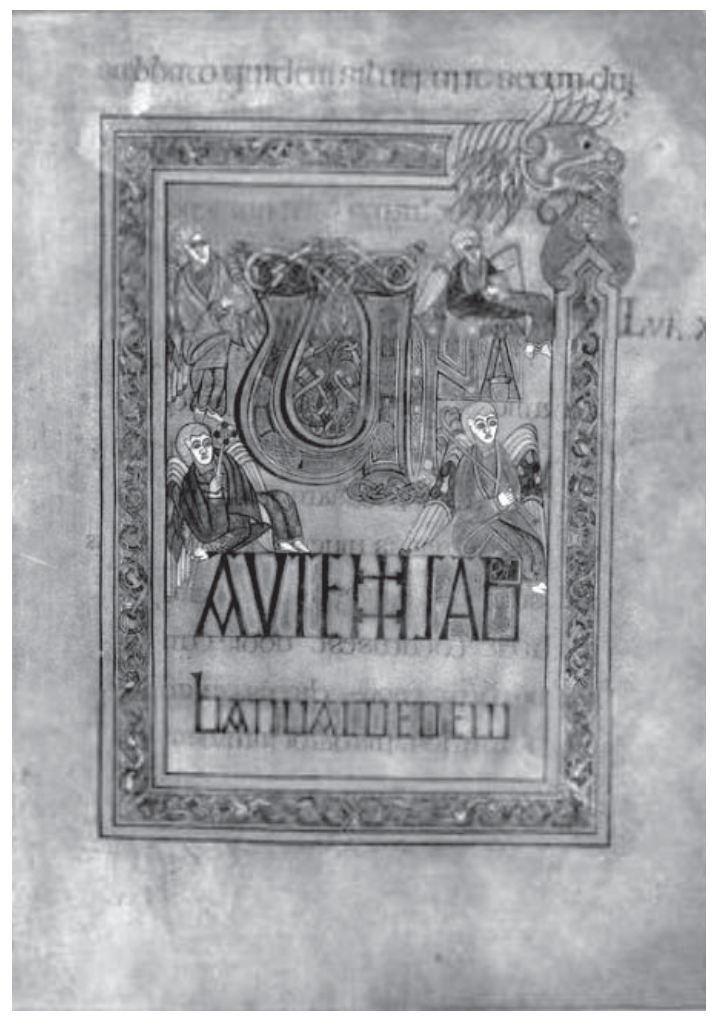

Fot. 33. Ozdobne zdanie: Una autem sabbati valde (f.285r)

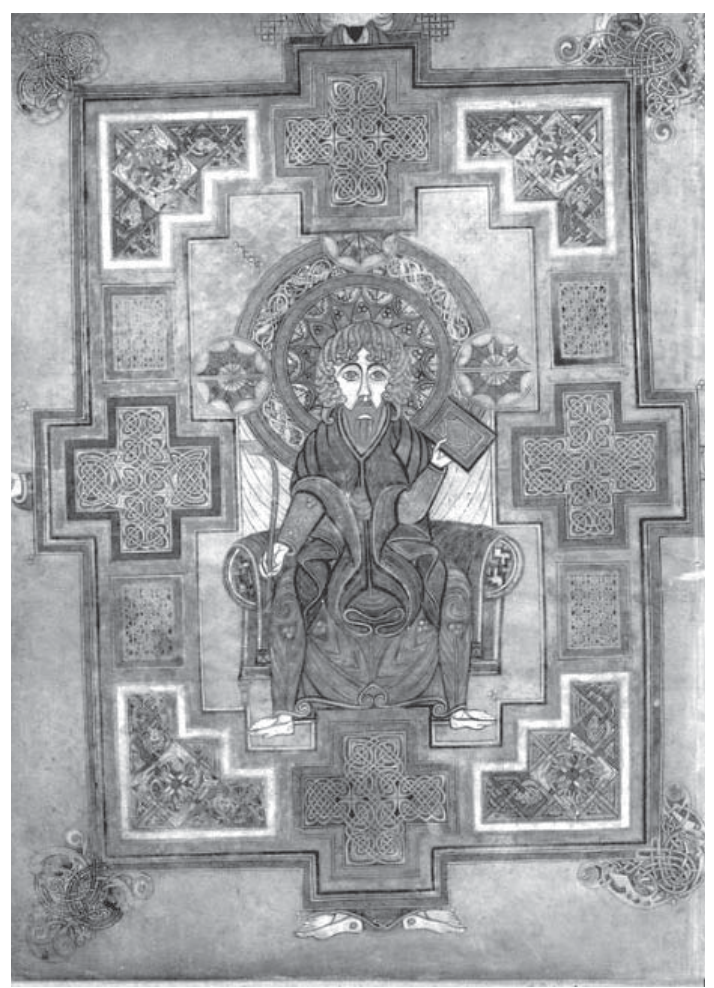

Fot. 35. Portret św. Jana (f.291v)

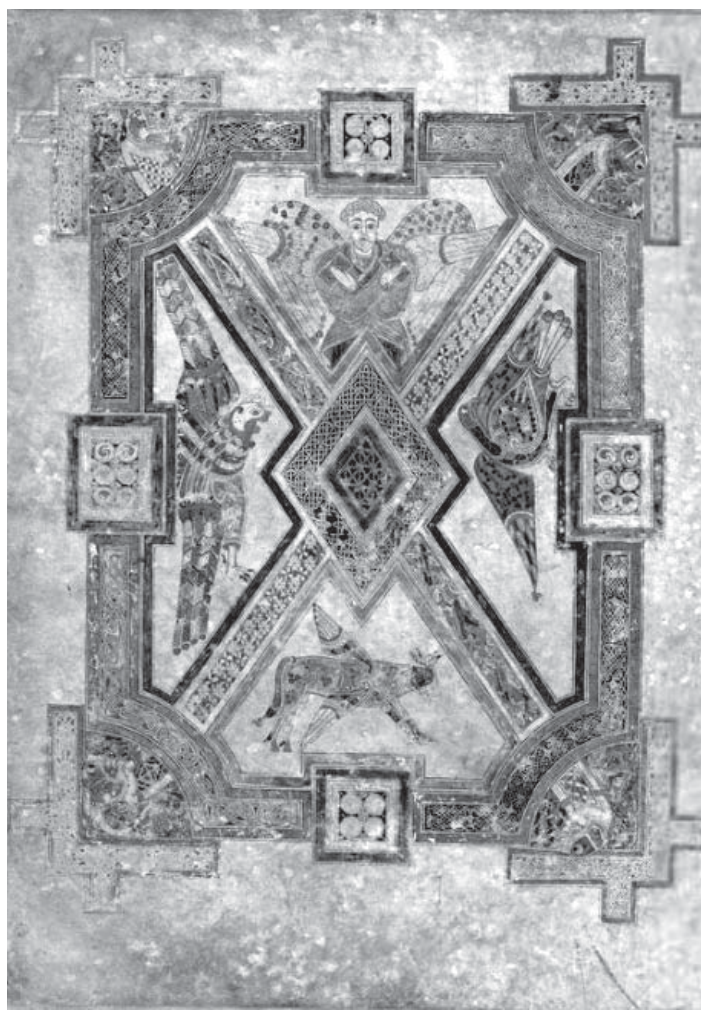

Fot. 34. Symbole Czterech Ewangelistów (f.290v)

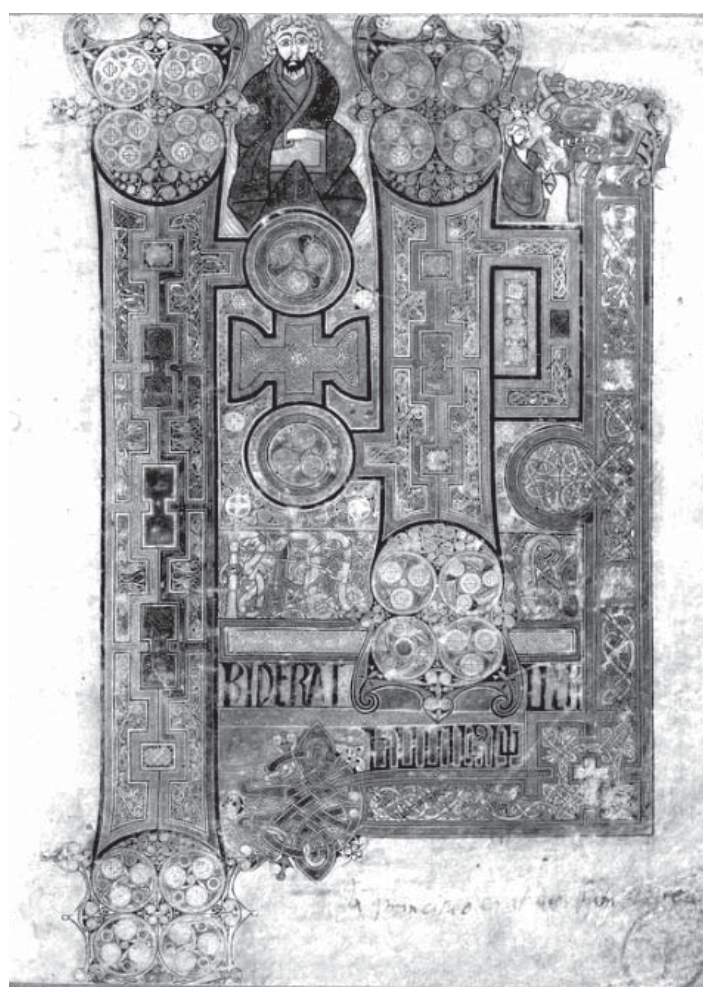

Fot. 36. Ozdobny inicjał początku Ewangelii św. Jana (f.291r) 
THE MOST BEAUTIFUL MEDIEVAL MANUSCRIPT - THE BOOK OF KELLS

\begin{abstract}
Summary
The Book of Kells (latin Codex Cenannensis, Irish: Leabhar Cheanannais), also known as the Gospels of Kells or the Gospels of St. Columba - a manuscript believed to have been created c. 800 , richly illuminated by Celtic monks from the monastery on the island of Iona. The manuscript is considered to be one of the most valuable and important monuments of Irish Christianity and works of Gaelic art, which survived to our times. Its fame rests mainly on glamor and artistry decorations that have no equal. Great compositions filling entire pages, craftsmanship decorations and ornamentation of initials used to highlight the text, make The Book of Kells a unique and unrepeatable work of art.

Since the mid-seventeenth century The Book of Kells is permanently stored in the Library of Trinity College Dublin (signature MS 58). In 2011 it has been inscribed on the UNESCO Memory of the World Register.
\end{abstract}

Keywords: medieval manuscript, Irish manuscript, Book of Kells, Gospel book of Kells, Abbey of Kells, Trinity College, Dublin, Irish monks in Iona, illuminated manuscript in the 8th or early 9 th century 